\title{
A PROPOSAL FOR THE INDEXATION OF DEBT \\ FOR INFLATION
}

\author{
JOEL MICK†
}

\section{INTRODUCTION}

This Comment is concerned with the effects of inflation on the taxation of debt. The current approach to the taxation of debt creates several inflation-induced inequities and economic distortions. Some of these inequities and distortions result directly from the taxation of nominal interest which leads to the overstatement of real interest income and expense. Others derive from the advantageous tax treatment accorded other forms of capital income relative to the treatment of interest income. Although the latter inequities and distortions exist even under inflation-free conditions, they are magnified by the existence of inflation. This Comment considers the feasibility of eliminating these inequities and distortions by altering the taxation of debt to account properly for the effects of inflation.

As a theoretical matter, the merit of indexing debt for inflation has been widely recognized. ${ }^{1}$ Yet significant disagreement remains over the administrability of any actual indexation scheme. ${ }^{2}$ Therefore, rather than recapitulate the detailed theoretical arguments in favor of indexation, this Comment focuses on the administrative and transitional issues that would arise in the implementation of debt indexation, topics that have not been addressed as thoroughly in the existing academic literature.

The magnitude of the inequities and economic distortions that result from the taxation of nominal interest increases dramatically

† B.A. 1983, University of Pennsylvania; J.D. Candidate 1993, University of Pennsylvania. The author wishes to thank Professor Reed Shuldiner for his guidance and support throughout the writing of this Comment.

1 See Daniel Halperin \& Eugene Steuerle, Indexing the Tax System for Inflation, in UNEASY COMPROMISE: PROBLEMS OF A HYBRID INCOME-CONSUMPTION TAX 347, 373 (Henry J. Aaron et al. eds., 1988); see also John Bossons, Indexing for Inflation and the Interest Deduction, 30 WAYNE L. REv. 945, 945 (1984); Eugene Steuerle, Tax Arbitrage, Inflation, and the Taxation of Interest Payments and Receipts, 30 WAYNE L. REV. 991, 1011-12 (1984); Joseph E. Stiglitz, On the Almost Neutrality of Inflation, in DEVELOPMENT IN AN INFLATIONARY WORLD 419, 419-20 (M. June Flanders \& Assaf Razin eds., 1981).

${ }^{2}$ See Henry J. Aaron, Inflation and the Income Tax: An Introduction, in INFLATION AND THE INCOME TAX 1, 29 (Henry J. Aaron ed., 1976); Halperin \& Steuerle, supra note 1 , at 359 . 
with higher maximum tax rates and elevated levels of anticipated inflation. ${ }^{3}$ This suggests that debt indexation is less important now than it was in the late 1970 s and early 1980 s, when both tax rates and inflation were significantly higher. Yet, lower tax rates and reduced inflation also mean that the transitional effects of adopting debt indexation would be much smaller now than were reform to await renewed inflation and increased tax rates. ${ }^{4}$ Thus, debt indexation remains a reform worthy of serious consideration even in the present economic climate.

This Comment is divided into five sections. Part $I$ begins with a brief discussion of the normative assumptions that underlie many of the arguments made later. The economic effects of our present method of taxing debt are then presented through a series of numerical examples. Part II summarizes the inequities and economic distortions that result from the failure to index debt for inflation. Part II also discusses the revenue effects of debt indexation and provides an overview of the relevant administrability issues. Part III considers several general topics in the implementation of debt indexation. These topics include the choice between partial and comprehensive tax base indexation, the timing of the indexation adjustment, the proper measurement of inflation, and problems of distinguishing debt from other assets. Part IV considers the issue of transition rules. After rejecting a number of familiar rules, a novel transition scheme for debt indexation is proposed and defended. Finally, Part V suggests specific methods of administering debt indexation for various classes of debt.

\section{ECONOMIC EFFECTS OF INFLATION ON DEBT}

This Comment assumes that the correct tax base under the federal income tax system is income rather than consumption. ${ }^{5}$

${ }^{3}$ See Aaron, supra note 2, at 27; Halperin \& Steuerle, supra note 1, at 349.

4 See infra note 164.

${ }^{5}$ The difference between an income tax and a consumption tax is that under a consumption tax, unconsumed income is not taxed when earned. For a theoretical comparison of income and consumption taxes, see HARVEY S. ROSEN, PUBLIC FINANCE 468-77 ( $2 \mathrm{~d}$ ed. 1988). Under a pure consumption tax, investment income, including interest income, is not taxed per se, so the problem of properly measuring interest income disappears. See Bossons, supra note 1, at 947.

Our present federal income tax system is, of course, a hybrid of income-type and consumption-type taxation. Taxation of many forms of income is deferred, although this deferral does not always extend until the income is ultimately consumed. See, e.g., I.R.C. $\$ 219$ (1988) (providing deduction for contributions to individual retirement accounts); id. $\S 404$ (providing deduction for contributions to qualified pension 
This assumption is necessary to establish a normative framework in which to discuss the taxation of debt, a framework that our present hybrid of income and consumption taxation cannot offer. ${ }^{6}$ This Comment also adopts the classic Haig-Simons definition of income. ${ }^{7}$ According to the Haig-Simons definition, income is the value of a person's rights that can be consumed without altering the value of his pre-existing store of rights. ${ }^{8}$ This value is properly measured by the potential quantity of real goods and services that an individual could consume, rather than in nominal monetary terms. ${ }^{9}$ Because an administrable tax system must assess income in monetary terms, a tax based on Haig-Simon income requires some form of adjustment to compensate for the decreasing real value of money due to inflation.

Inflation affects the taxation of income under the Internal Revenue Code ("the Code") in two ways. First, inflation affects the tax rate structure by reducing the real value of all nominal dollar amounts in the Code. ${ }^{10}$ This effect is easily eliminated by automatically increasing these dollar figures based on the rate of

plans). To the extent that some mix of consumption and income taxation is desirable, this mix can be achieved through provisions deferring taxation of specified forms of income. Nonetheless, absent any special justification for deferring taxation of income, it is assumed in this Comment that income should be taxed when it is earned. See Alvin C. Warren, Jr., Fairness and a Consumption-Type or Cash Flow Personal Income Tax, 88 HARV. L. REV. 931 (1975) (defending the income tax ideal). But see William D. Andrews, A Consumption-Type or Cash Flow Personal Income Tax, 87 HARV. L. REV. 1113 (1974) (advocating a consumption-based tax); William D. Andrews, Fairmess and the Personal Income Tax: $A$ Reply to Professor Warren, 88 HaRv. L. REV. 947 (1975) (defending the fairness of a consumption-based tax).

${ }^{6}$ Our present tax system contains elements of both income-type and consumption-type taxation, but it does not choose between them in any principled way. Without such an underlying principle, it is impossible to make strong claims about the proper taxation of debt.

6 7 See Henry C. Simons, Personal income Taxation 49 (1938).

${ }^{8}$ See id. Conformity with this ideal of income would require full accrual taxation. Our present system is a hybrid of realization-based and accrual taxation, and consistency with existing law will often support realization-based taxation in cases where consistency with the Haig-Simons ideal would reject such treatment. Although this conflict admits no ideal solution, accrual taxation in accord with the Haig-Simons ideal is assumed in this Comment to be preferable unless it would create significant administrative difficulties or enhanced tax arbitrage opportunities.

${ }^{9}$ See Roger E. Brinner, Inflation and the Definition of Taxable Personal Income, in INFLATION AND THE INCOME TAX, supra note 2, at 121-23.

${ }^{10}$ See Aaron, supra note 2, at 5, 20-21 (noting that "inflation changes the rate structure," primarily through decreasing the real value of personal exemptions, dollarlimited credits, the standard deduction, and the size of the income brackets); Bossons, supra note 1, at $952 \mathrm{n} .15$ (discussing the effect of inflation on the tax brackets). 
inflation. ${ }^{11}$ Second, inflation distorts the tax base by increasing taxpayers' nominal income, causing them to pay tax on a greater income than they would in the absence of inflation. ${ }^{12}$ With respect to debt, inflation increases interest rates, and higher interest rates result in higher nominal interest income. ${ }^{13}$ The inflationinduced component of interest is, in an economic sense, a partial repayment of debt principal. Like other recoveries of capital, it should not be treated as income or expense under the Haig-Simons definition. Taxation of nominal interest under the present Code incorrectly measures creditors' real income and debtors' real expense on indebtedness by treating this inflation-induced component of interest as taxable. ${ }^{14}$ The following series of examples illustrates the proper tax treatment of debt under inflationary conditions and the economic effects of our present departure from this ideal.

Example 1: $\mathrm{C}$ agrees to lend $\mathrm{D}$ the sum of $\$ 100$ for a period of one year. Both $C$ and $D$ anticipate an inflation rate of $5 \%$ and both agree that $\mathrm{C}$ should receive an anticipated real rate of return of $2 \%$. There is no credit risk ${ }^{15}$ and there are no taxes.

Absent taxes and credit risk, the nominal interest rate should theoretically follow the formula:

$$
r_{\text {money }}=\left(1+r_{\text {real }}\right) \times\left(1+i_{a}\right)-1
$$

11 Many of these figures are already indexed to increases in the Consumer Price Index. See infra note 129.

12 See Aaron, supra note 2, at 5-6.

13 Under inflationary conditions, creditors will demand increased nominal interest rates because they must receive an additional return on the funds they loaned in order to maintain the real value of these funds over the term of the debt. Debtors will agree to pay higher nominal interest rates because they will be repaying the debt principal in deflated dollars. See infra note 16 and accompanying text.

14 Inflation also distorts the measurement of capital gains and losses, depreciation deductions, and the cost of materials used (inventory). Net capital income is measured by taking gross receipts from capital and subtracting any related capital expenditures. Distorted measurement of capital income occurs under inflationary conditions because receipts from capital and the corresponding capital expenditures are often measured in dollars of significantly different real value. See generally Aaron, supra note 2, at 6-14 (discussing the effects of inflation on the correct measurement of depreciation deductions, capital gains and losses, and inventory valuation for tax purposes). None of these areas of inflation-induced tax base distortion-debt, capital gains, depreciation allowances, and inventories-are indexed under the present Code.

${ }^{15}$ Credit risk, also known as default risk, is the risk that the debtor will be unable to satisfy his debt obligation. Where a risk of default exists, the interest rate also includes a default premium to compensate the creditor for his possible loss of capital. See FrANK J. FABOZZI ET AL., THE HANDBOOK OF FIXEd INCOME SECURITIES 33 (3d ed. 1991). 
where $r_{\text {money }}$ is the nominal interest rate, $r_{\text {real }}$ is the real interest rate, and $i_{a}$ is the anticipated rate of inflation. ${ }^{16}$ Based on this formula, the interest rate in Example 1 would be $7.10 \% .{ }^{17}$ Assuming that the parties did agree on an interest rate of $7.10 \%$, at the end of the year, $C$ would receive $\$ 107.10$ from $D$. Of this amount, $\$ 100.00$ would constitute a return of nominal principal and $\$ 7.10$ would constitute nominal interest. Yet, of this $\$ 107.10, \$ 105.00$ actually constitutes anticipated return of real principal, because $\$ 105.00$ one year in the future has the same anticipated real value as $\$ 100.00$ has at present. ${ }^{18}$ The remaining $\$ 2.10$ constitutes anticipated real interest at a rate of $2 \%$, also in deflated dollars. ${ }^{19}$

The previous interest rate formula can be rewritten as:

$$
r_{\text {money }}=r_{\text {real }}+i_{a}+\left(r_{\text {real }} \times i_{a}\right)
$$

where the real interest rate and the anticipated rate of inflation are small, the cross-product, $r_{\text {real }} \mathrm{x} i_{a}$, is much smaller than the sum, $r_{\text {real }}$ $+i_{a}$, and can be ignored with little loss of accuracy. ${ }^{20}$ This results in the approximate interest rate formula:

$$
r_{\text {moncy }}=r_{\text {real }}+i_{a^{\circ}} \text {. }
$$

Using this approximate formula, the interest rate in Example 1 would be $7 \% .^{21}$ For the sake of simplicity, this approximate interest rate formula is used for the remainder of this Comment.

${ }^{16}$ For the classic presentation of this model of interest rates, see IRVING FISHER, THE THEORY OF INTEREST (Augustus M. Kelley Bookseller 1967) (1930). See generally RICHARD BREALEY \& STEWART MYERS, PRINCIPLES OF CORPORATE FINANCE 558-61 (4th ed. 1991) (discussing the propriety of Fisher's theory). For a modern statement, see id. at 559. Critics of Irving Fisher's theory have challenged the assumption that the real interest rate is unresponsive to changes in the rate of anticipated inflation. See infra note 29. This Comment proceeds under the assumption that Fisher's formula is approximately correct. Empirical evidence supports this position. See, e.g., BREALEY \& MYERS, supra, at 560-61 (determining that a restatement of Fisher's formula produced results only "a little less than we should expect if Fisher is right") (citing Eugene F. Fama, Short-Term Interest Rates as Predictors of Inflation, 65 AM. ECON. REv. $269,269-282(1975))$.

$$
170.0710=(1+0.02) \times(1+0.05)-1 \text {. }
$$

Percentages and their decimal equivalents will be used interchangeably throughout this Comment.

$18 \$ 105=\$ 100 \times(1+0.05)$.

$19 \$ 2.10=\$ 100 \times 0.02 \times(1+0.05)$.

${ }^{20}$ For example, where the real interest rate and the anticipated rate of inflation are both $10 \%$, the cross-product is $1 \%$, whereas the sum is $20 \%$. Even at these rates, the inaccuracy in calculating the nominal interest rate resulting from ignoring the cross-product term is only 5\%. See BREALEY \& MYERS, supra note 16, at 559.

$210.07=0.02+0.05$. 
Example 2: The facts are identical to those in Example 1, except that $\mathbf{C}$ and $\mathrm{D}$ both face a $50 \%$ marginal tax rate. ${ }^{22}$ Debt is indexed for inflation, meaning that the portion of nominal interest that is necessary to maintain the real value of the debt principal is excluded from taxation. The parties agree that $\mathrm{C}$ should receive an anticipated, real pre-tax rate of return of $2 \%^{23}$ and that $D$ should pay an anticipated, real pre-tax interest rate of $2 \%$.

Where debt is indexed for inflation, the interest rate should still follow the formula given in Example 1. ${ }^{24}$ In Example 2, this means that $C$ will receive interest at a rate of $7 \% .{ }^{25}$ At the end of one year, $C$ will receive $\$ 107$, of which $\$ 7$ will be nominal interest. The parties anticipate an inflation rate of $5 \%$, so they anticipate that $\$ 5$ of this nominal interest will be excluded from taxation. ${ }^{26}$ Expected, real pre-tax interest is therefore $\$ 2,{ }^{27}$ for an anticipated, real pre-tax interest rate of $2 \% .^{28}$

Example 2A: The facts are identical to those in Example 2, except that debt is not indexed for inflation. Any interest paid is fully includable in income to $\mathrm{C}$ and fully deductible for $\mathrm{D}$.

The general interest rate formula under proportional taxation of full nominal interest income is:

$$
r_{\text {money }}=r_{\text {real }}+i_{a}+\left[i_{a} \times t /(1-t)\right]
$$

where $t$ is the taxpayer's marginal tax rate. ${ }^{29}$ For $C$ to receive an

${ }^{22}$ A taxpayer's marginal tax rate is the rate of tax that he will pay on his next dollar of income. See MARVIN A. CHIRELSTEIN, FEDERAL INCOME TAXATION 4 (6th ed. 1991). The marginal tax rate thus determines how much an additional dollar of income or deduction will be worth to a particular taxpayer. The marginal tax rate is not the same as the average tax rate. A taxpayer's average tax rate is the percentage of that taxpayer's total income represented by his total tax liability. See id. All future references to tax rates refer to marginal rather than average rates.

${ }^{23}$ If subject to a $50 \%$ tax, $C$ will not demand that his real after-tax rate of return remain at $2 \%$, as it was in Example 1, because $C$ 's real after-tax rate of return from other forms of capital will also be subject to the same $50 \%$ tax.

${ }^{24}$ See supra formula in text accompanying note 21 .

${ }^{25} 0.07=0.02+0.05$.

$26 \$ 5=\$ 100 \times 0.05$.

$27 \$ 2=\$ 7-\$ 5$.

${ }^{28} 0.02=\$ 2 / \$ 100$.

29 See Martin Feldstein, Inflation, Income Taxes, and the Rate of Interest: A Theoretical Analysis, 66 AM. ECON. REV. 809, 813 (1976); Vito Tanzi, Inflation, Indexation and Interest Income Taxation, Q. REV., Mar. 1976, at 64, 73. This formula assumes that real interest rates are unresponsive to changes in tax rates and the expected rate of inflation. These assumptions are not uniformly accepted. See, e.g., Fiscal Aff. Dep't, Int'l Monetary Fund, Interest Rates and Tax Treatment of Interest Income and Expense, in TAXATION, INFLATION, AND INTEREST RATEs 3, 16-22 (Vito Tanzi ed., 1984) (discussing factors which would make real interest rates responsive to changes in the expected 
after-tax inflationary component, $i_{a}$, of $5 \%$, the interest rate must contain an additional tax-on-anticipated-inflation component, $i_{a} \times$ $t /(1-t)$, of $5 \%,{ }^{30}$ resulting in a nominal interest rate of $12 \% .{ }^{31}$ At the end of one year, $C$ would receive $\$ 112$, of which $\$ 12$ would be nominal interest. $C$ would pay a tax of $\$ 6$ on this $\$ 12$ of nominal interest income, and $D$ would receive a $\$ 6$ tax savings from his $\$ 12$ interest deduction. ${ }^{32}$ Of the remaining $\$ 6$ of after-tax interest, $\$ 5$ represents anticipated return of principal ${ }^{33}$ and $\$ 1$ represents anticipated, real after-tax interest. ${ }^{34}$ At a $50 \%$ tax rate, this is equivalent to $\$ 2$ of anticipated, real pre-tax interest, ${ }^{35}$ for an anticipated, real pre-tax interest rate of $2 \% .^{36}$

In Example 2, where debt was indexed for inflation, the parties agreed to a nominal interest rate of $7 \%$ that resulted in an expected, real pre-tax interest rate of $2 \%$ for both the creditor and the debtor. In Example 2A, where debt was not indexed, the parties agreed to a nominal interest rate of $12 \%$ that also yielded an anticipated, real pre-tax interest rate of $2 \%$ for both parties. Examples 2 and $2 \mathrm{~A}$ thus demonstrate that where creditors and debtors face the same marginal tax rate, they are able to compensate exactly for the taxation of nominal interest by increasing the agreed upon interest rate. ${ }^{37}$ This ability does not exist, however, where creditors and debtors face different tax rates, as the following examples demonstrate.

rate of inflation or tax rate); Menachem Katz, Inflation, Taxation, and the Rate of Interest in Eight Industrial Countries, 1961-82, in TAXATION, INFLATION, AND INTEREST RATES, supra, at 172 (presenting empirical data supporting the responsiveness of interest rates to inflation). This comment proceeds under the assumption that this interest rate formula is sufficiently accurate to demonstrate the need for debt indexation and to serve as the basis for developing and evaluating a transition scheme for its implementation.

${ }^{30} 0.05=0.05 \times 0.50 /(1-0.50)$.

$310.12=0.02+0.05+0.05$.

$32 \$ 6=\$ 12 \times 0.50$.

$39 \$ 5=\$ 100 \times 0.05$.

$34 \$ 1=\$ 6-\$ 5$.

$35 \$ 2=\$ 1 /(1-0.50)$.

${ }^{36} 0.02=\$ 2 / \$ 100$.

37 See generally Michael C. Durst, Inflation and the Tax Code: Guidelines for Policymaking, 73 MINN. L. REv. 1217, 1253 (1989) (stating that competitive market forces dictate that the taxation of nominal interest would have "no significant consequences if the borrower and lender shared the same marginal tax rate" (footnote omitted)). 
Example 3: The facts are identical to those in Example 2 except that $\mathrm{C}$ now faces a tax rate of $10 \%$, while $\mathrm{D}$ still faces a tax rate of $50 \%$.

Under a system of debt indexation, real pre-tax rates of return remain constant regardless of the marginal tax rates faced by creditors and debtors. Thus, according to the formula given in Example 1, $C$ would receive a nominal interest rate of $7 \% .^{38}$ As in Example 2, the parties still anticipate that $\$ 5$ of nominal interest will be excluded from taxation. ${ }^{39} C$ anticipates $\$ 2$ of real pre-tax interest income, for a real, pre-tax rate of return of $2 \% .{ }^{40}$ Similarly, $D$ anticipates a $\$ 2$ interest deduction, for a real pre-tax interest rate of $2 \%$. Subject to certain refinements, Example 3 demonstrates the method of taxing debt advocated by this Comment.

Example 3A: The facts are identical to those in Example 3, except that debt is not indexed for inflation. Any interest paid is fully includable in income to $\mathbb{C}$ and fully deductible for $D$.

As in Example 2A, $D$ will still be willing to pay an interest rate of $12 \%$, because it will yield him an anticipated, real pre-tax interest rate of $2 \%{ }^{41}$ However, because $C$ anticipates facing only a $10 \%$ tax, he will require a nominal interest rate of only $7.56 \%$ to achieve an anticipated, real, pre-tax interest rate of $2 \%{ }^{42}$ If he received nominal interest of $\$ 7.56, C$ would pay $\$ 0.76$ in taxes. Of the remaining $\$ 6.80, \$ 5.00$ would compensate $C$ for anticipated inflation, and $\$ 1.80$ would be anticipated, real after-tax income. At a $10 \%$ tax rate, this is equivalent to $\$ 2.00$ of real pre-tax income. ${ }^{43}$ Thus, at a nominal interest rate of $7.56 \%, C$ would anticipate a real, pre-tax rate of return of $2 \%$.

If $C$ were the only potential creditor and $D$ the only potential debtor, the agreed upon interest rate would be somewhere between 7.56 and $12 \%$, depending on the relative bargaining power of the parties. $C$ and $D$ would, in effect, split the tax benefit created by the taxation of nominal interest. Assuming that the parties agreed upon a nominal interest rate of $9 \%, C$ would receive $\$ 9.00$ of

${ }^{38} 0.07=0.02+0.05$.

${ }^{39} \$ 5=\$ 100 \times 0.05$.

$400.02=\$ 2 / \$ 100$.

${ }^{41} 0.12=0.02+0.05+[0.05 \times 0.50 /(1-0.50)]$. See supra note 29 and accompanying text.

$420.0756=0.02+0.05+[0.05 \times 0.10 /(1-0.10)]$. See supra note 29 and accompanying text.

$43 \$ 2.00=\$ 1.80 /(1-0.10)$. 
nominal interest income, ${ }^{44}$ on which he would pay a tax of $\$ 0.90 .45$ Of the remaining $\$ 8.10$ of after-tax income, $\$ 5.00$ would compensate $C$ for anticipated inflation, leaving $C$ an anticipated, real after-tax return of $\$ 3.10$. This is $\$ 1.30$ more than $C$ needed to obtain a real, pre-tax rate of return of $2 \%{ }^{46}$ This real after-tax return of $\$ 3.10$ is equivalent to a real pre-tax return of $\$ 3.44 .{ }^{47} \mathrm{C}$ therefore enjoys an anticipated, real pre-tax interest rate of $3.44 \%$. At a nominal interest rate of $9 \%, D$ will have a $\$ 9.00$ deductible interest expense. At $D$ 's marginal tax rate of $50 \%$, this deduction will produce a $\$ 4.50$ tax savings. ${ }^{48} \mathrm{D}$ will be left with an anticipated, nominal after-tax expense of $\$ 4.50$. The component of interest that constitutes anticipated repayment of principal due to inflation is $\$ 5.00$, resulting in an anticipated, real after-tax interest expense of $-\$ 0.50 .^{49}$ This after-tax expense of $-\$ 0.50$ is $\$ 1.50$ less than the $\$ 1.00$ that $D$ would be willing to pay to achieve a pre-tax interest rate of $2 \%,{ }^{50}$ and is equivalent to a pre-tax interest expense of $\$ 1.00 .^{51} D$ therefore enjoys an anticipated, real pre-tax interest rate of $-1.00 \%$. Together, $C$ and $D$ enjoy a tax benefit of $\$ 2.80$ under nominal taxation of debt. ${ }^{52}$ This benefit entails a corresponding $\$ 2.80$ loss in tax revenue. ${ }^{53}$

$44 \$ 9=\$ 100 \times 0.09$.

$45 \$ 0.90=\$ 9 \times 0.10$.

$46 \$ 1.30=\$ 3.10-\$ 1.80$. See supra note 43 and accompanying text.

$47 \$ 3.44=\$ 3.10 /(1-0.10)$.

$48 \$ 4.50=\$ 9.00 \times 0.50$.

$49-\$ 0.50=\$ 4.50-\$ 5.00$.

${ }^{50}$ To achieve a pre-tax interest rate of $2 \%, D$ would be willing to incur an anticipated, pre-tax interest expense of $\$ 1$. One dollar of pre-tax expense is equivalent to $\$ 2$ of after-tax expense of $\$ 2$. $(\$ 2=\$ 1 /(1-0.50))$.

$51-\$ 1.00=-\$ 0.50 /(1-0.50)$.

$52 \$ 2.80=\$ 1.30+\$ 1.50$.

53 If debt were indexed, as in Example 3, the loan would result in a $\$ 0.80$ revenue loss because $C$ would receive $\$ 2$ of income taxable at $10 \%$, while $D$ would receive a $\$ 2$ deduction at $50 \%$. This revenue loss is appropriate because it results from the taxation of real gains and losses actually recognized by taxpayers. See Frederic W. Hickman, Interest, Depreciation, and Indexing, 5 VA. TAX REV. 773, 802 (1986). In Example 3A, the total revenue loss is $\$ 3.60$ because the full $\$ 9$ of nominal interest is taxable to $C$ at $10 \%$ while being deductible by $D$ at $50 \%$. The difference of $\$ 2.80$ between Example 3 and Example 3A is the revenue cost of taxing nominal rather than real interest.

Taxation of nominal interest also results in a revenue gain for some debt. Where the debtor faces a lower tax rate than the creditor, or where interest is not fully deductible by the debtor, the increase in the creditor's taxable interest income can produce more revenue than will be lost by the debtor's increased interest deduction. The aggregate revenue effect of taxing nominal interest can only be ascertained by considering the relative tax rates faced by debtors and creditors and the extent to 
If $C$ and $D$ are instead transacting in an open market, the actual interest rate will depend on market forces rather than individual bargaining strengths. These market forces will determine a breakeven marginal tax rate, $t^{*}$, such that both creditors and debtors facing that marginal rate are indifferent between indexed and unindexed taxation of debt. ${ }^{54}$ Debtors facing a marginal tax rate above the breakeven rate will benefit from full taxation of nominal interest, because their higher interest deductions will produce a greater tax savings than the tax-on-anticipated-inflation component of interest they will be forced to incur. ${ }^{55}$ Similarly, creditors facing a marginal tax rate below the breakeven rate will benefit from taxation of nominal interest, because their increased tax liability will be less than the tax-on-anticipated-inflation component of interest they will receive. Debtors facing a marginal rate below the breakeven rate and creditors facing a marginal rate above the

which interest expenses are not fully deductible. See infra part II.C for a general discussion of this issue.

${ }^{54}$ This breakeven marginal rate can be calculated from the formula in Example 2A by solving for $t$. This yields the formula:

$$
t^{*}=1-\left[i_{a} /\left(r_{\text {moncy }}-r_{\text {real }}\right)\right] \text {. }
$$

Unfortunately, this formula involves variables that are difficult to measure accurately. As one observer has noted:

A substantial body of empirical research has attempted to measure the magnitude of the "breakeven" marginal tax rate reflected in the responsiveness of interest rates to changes in the rate of inflation. Unfortunately, such measurement is difficult, in part because the key variable to which interest rates should on theoretical grounds be responsive-the expected inflation rate-is by its nature unobservable. Tests of the impact of inflation on interest rates are thus only as good as the models of expectation formation in which they are based. The resultant uncertainty about econometric analyses does not permit a strong conclusion to be drawn.

Bossons, supra note 1 , at 956.

${ }^{55}$ Under taxation of nominal interest, a debtor will receive an interest deduction that is $i_{a} /\left(1-t^{*}\right)$ higher than under a system of debt indexation. $\left(i_{a} /\left(1-t^{*}\right)=i_{a}+\right.$ $\left.\left[i_{a} \times t^{*} /\left(1-t^{*}\right)\right]\right)$. This increased deduction will produce a tax savings for the debtor of $i_{a} \times t /\left(1-t^{*}\right)$, where $t$ is the debtor's marginal tax rate. To compensate creditors for increased taxable interest income, debtors will also incur an additional tax-onanticipated-inflation component of interest of $i_{a} \times t^{*} /\left(1-t^{*}\right)$. See supra note 29 and accompanying text. For debtors facing a marginal tax rate, $t$, greater than the breakeven marginal rate, $t$, the tax savings from taxation of nominal interest will exceed the higher interest costs. For debtors facing a marginal tax rate below the breakeven rate, the costs will exceed the benefits.

This analysis extends easily to creditors, for whom the benefits and burdens of taxing nominal interest are simply reversed. Thus, it follows that creditors facing a marginal tax rate below the breakeven marginal rate will receive a net benefit from taxation of nominal interest and that creditors facing a rate above the breakeven rate will experience a net detriment. 
breakeven rate will be disadvantaged by the absence of indexation. ${ }^{56}$ This example demonstrates the primary economic consequences of our present system of debt taxation.

The foregoing discussion demonstrates that in a progressive tax system, lack of debt indexation results in inequity among debtors facing different marginal tax rates. Debtors subject to the breakeven tax rate will face the same real pre-tax interest rate as they would have faced under debt indexation. Debtors subject to a tax rate below the breakeven rate will face a higher effective interest rate, while debtors subject to a tax rate above the breakeven rate will face a lower interest rate. Similarly, lack of indexation results in inequity among creditors facing different marginal tax rates, although here it is higher bracket creditors who are disadvantaged relative to lower bracket creditors. ${ }^{57}$ In addition to producing inequities, rules that overtax one side of a transaction while undertaxing the other side encourage taxpayers in different brackets to align themselves in a way that minimizes their combined tax liability. This self-selection of taxpayers is known as a "tax clientele" effect. ${ }^{58}$ With respect to the full taxation of nominal interest, the overtaxed side is the creditor, and this side will disproportionately attract low-bracket and zero-bracket taxpayers. The undertaxed side, in this case, the debtor, will disproportionately attract highbracket taxpayers. ${ }^{59}$ This alignment of taxpayers results in several

${ }^{56}$ See supra note 55 .

57 For a full discussion of the inequities resulting from the taxation of nominal interest, see infra part II.A.

${ }^{58}$ See Bossons, supra note 1, at 956 n.23.

59 See 2 U.S. TREASURY DEP'T, TAX REFORM FOR FAIRNESS, SIMPLICITY, AND ECONOMIC GROWTH 194 (1984) [hereinafter TREASURY I].

[I]n a progressive tax system, overstatement of interest expense and income accentuates the existing incentive for lower tax-bracket taxpayers (including tax-exempt institutions) to be net creditors and higher tax-bracket taxpayers to be net borrowers. This so-called "clientele effect" occurs because the tax savings from interest deductions is greater for high-bracket borrowers than is the increased tax liability from interest income to low-bracket lenders. This clientele effect is aggravated during times of high inflation and corresponding high nominal interest rates.

Id. Bossons notes:

Both individual tax avoidance and tax arbitragbe [sic] transactions result in a reallocation of assets among taxpayers ... so that interest-bearing financial assets are held to a greater extent than otherwise would be the case by investors in low tax brackets (e.g., pension funds). Taxpayers in high tax brackets (wealthy individuals, taxable corporations) are encouraged to hold tax sheltered assets and to finance a greater portion of their investments by borrowing. 
economic distortions ${ }^{60}$ in addition to producing a revenue loss for the Treasury. 61

\section{NORMATIVE ANALYSIS OF DEBT INDEXATION}

\section{A. Efficiency and Equity Considerations}

Even without inflation, income from debt is overtaxed relative to income from other forms of capital. Unlike debt, capital assets, depreciable assets, and inventories are each subject to preferential tax rules that reduce their effective rate of taxation. ${ }^{62}$ The extent of this overtaxation of interest income is increased under inflationary conditions. ${ }^{63}$ The existence of these extraneous tax preferences for other forms of capital can be viewed as a form of ad hoc indexation, at least to the extent that they are not motivated by independent policy considerations such as stimulating economic

Bossons, supra note 1 , at 950 .

${ }^{60}$ See infra part II.B.

${ }^{61}$ See infra part II.C.

62 See Halperin \& Steuerle, supra note 1, at 356 (" [A]lmost all forms of capital income receive some form of special treatment or ad hoc indexing under current law[,] ... [t]he major exception [being] interest income . ..."). The effective rate of taxation of income from capital assets is reduced by the tax deferral advantages of realization-based taxation, see I.R.C. $\$ \S 1001(c), 1031-1041$ (1988), the step-up in basis at death, see id. $\$ 1014$, and the tax-rate ceiling on capital gains, see id. $\$ \S 1(h), 1201$. The effective rate of taxation of income from depreciable assets is reduced by the accelerated depreciation allowances of Modified-ACRS. See id. $\$ 168$. At times it has also been reduced by investment tax credits. See id. $\$ \S 38,46-48$ (1982). The effective rate of taxation of income from inventories is reduced by the lower of cost or market valuation, see Treas. Reg. $\$ 1.471-4$ (1958), and by LIFO accounting, see I.R.C. $\$ 472$ (1988). See generally Halperin \& Steuerle, supra note 1, at 353-56 (discussing the various forms of ad hoc indexing under current law).

${ }^{63}$ Inflation increases nominal interest income, which is taxed currently at the taxpayer's marginal tax rate. Although inflation also increases nominal income from other forms of capital, taxation of this increased income is frequently deferred. See I.R.C. $\$ 1001$ (c) (1988) (deferring taxation of gain or loss on property until "sale or exchange"); $i d$. $\$ \S 1031-1041$ (deferring taxation of gain or loss on property under specified circumstances, even though there has been a "sale or exchange"); id. $\$ 168$ (permitting accelerated depreciation); id. $\$ 472$ (permitting deferral of inventory income by allowing LIFO accounting); Treas. Reg. 1.471-4 (1958) (permitting deferral of inventory income by allowing lower of cost or market accounting). This deferral is equivalent to taxing the deferred income at a lower tax rate. In the case of capital assets, taxation may actually occur at a lower rate. See I.R.C. $\$ \$ 1(h), 1201$ (1988). Because income from non-debt capital is taxed at a lower effective rate than interest income, inflation causes a greater incremental tax burden on interest income than on income from non-debt capital. Cf. Bossons, supra note 1, at 951 ("[O]ne of the primary effects of inflation is to magnify the impact of all of the distortions that occur in a non-inflationary environment."). 
growth. This does not mean that indexing these assets instead of providing ad hoc indexation through tax preferences would be worthless. It does, however, indicate that from the standpoint of efficiency and horizontal equity, debt is in greater need of indexation than other forms of capital. ${ }^{64}$

Under inflationary conditions, and absent any offsetting tax preferences, unindexed income from all forms of capital is also overtaxed relative to income from labor. ${ }^{65}$ Because it receives no extraneous tax preferences, ${ }^{66}$ interest income is overtaxed relative to labor income under conditions of inflation. The degree of this overtaxation increases with the rate of inflation and, thus, is theoretically unbounded. At times, the effective tax rate on interest income has substantially exceeded $100 \%{ }^{67}$ This horizontal inequity between taxpayers who derive income from labor and those who derive income from debt further supports the need for debt indexation. ${ }^{68}$

${ }^{64}$ See Halperin \& Steuerle, supra note 1, at 373 (comments of Mark Perlis)( ${ }^{\text {"While }}$ most commentators ... usually advocate indexing as a means of achieving more neutral taxation of current capital and labor income, the case for indexing is actually much stronger if consideration is given to seeking neutral tax treatment of capital income from different types of assets.").

${ }^{65}$ Net income, which is subject to taxation, is the amount of gross income that remains after subtracting the costs associated with producing that income. Capital income frequently occurs many years after the capital expenditures that helped produce it. Thus, expenses incurred in producing capital income are often measured in dollars with significantly greater purchasing power than the current dollars in which capital income is realized and in which income taxes will be paid. In such cases, simple netting of gross income and expense, with no adjustment for inflation, will greatly overstate real capital income. Labor income is not magnified by inflation in this way. There are relatively few expenses associated with producing labor income and such expenses generally occur in close temporal proximity to the labor income they help produce, making any inflationary loss de minimis. See Aaron, supra note 2, at 6; Halperin \& Steuerle, supra note 1, at 352-53.

${ }^{66}$ See supra note 62 and accompanying text.

67 The interest rate on short term Treasury bills reached $16.13 \%$ in 1981 . See Standard \& Poor's Corp., BOND GUIDE, Dec. 1981, at 8. The rate of inflation in 1981, as measured by the Consumer Price Index, was $10.3 \%$. See Bureau of Lab. Stats., U.S. Dep't of Labor, Current Labor Statistics, MONTHLY LAB. REV., Dec. 1990, at 59, 96. The maximum marginal tax rate for individuals at that time was 70\%. See I.R.C. \& 1 (Supp. IV 1980). Thus, the real after-tax rate of return for a top-bracket individual holding such a short term Treasury bill was $-4.95 \% .(-4.95 \%=[16.13 *(1-0.70)$ $10.3] /(100+10.3))$. This is equivalent to an effective tax rate of $130.6 \%$ on nominal interest income. $(130.6 \%=[16.13+4.95] / 16.13)$.

${ }^{68}$ This argument also applies, albeit to a lesser degree, to income from other forms of capital. See supra note 62 and accompanying text. It is possible to reject this claim of inequity by viewing the overtaxation of capital under inflationary conditions as a desirable source of additional progressivity in the tax system, because the wealthy 
Finally, under inflationary conditions, failure to index debt favors low-bracket creditors over high-bracket creditors and favors high-bracket debtors over low-bracket debtors. If debt is not indexed for inflation, market mechanisms will cause pre-tax interest rates to increase so that the after-tax interest rate will remain unchanged for taxpayers facing a specific breakeven marginal tax rate. ${ }^{69}$ Net creditors facing a marginal tax rate above this breakeven rate are undercompensated by this market adjustment, as are net debtors facing a marginal tax rate below this breakeven rate. Net debtors subject to a marginal tax rate above the breakeven rate and net creditors subject to a rate below the breakeven rate are overcompensated. ${ }^{70}$ This result is itself inequitable. Additionally, it encourages high-bracket taxpayers to become net debtors and low-bracket taxpayers to become net creditors. ${ }^{71}$ Implicated in this basic economic result are several other economic distortions. Although a full analysis is beyond the scope of this Comment, brief mention will be given to the most important of these distortions. ${ }^{72}$

First, real after-tax interest rates may be low or even negative for high-bracket debtors. In order to support as much tax-favored borrowing as possible, these taxpayers prefer to invest in low-risk, easily leveraged assets even though such assets may have a much lower rate of return than other assets that require greater equity. ${ }^{73}$ Second, the tax subsidy on borrowing leads to a distorted allocation

receive a disproportionate fraction of capital income. But even if increased progressivity is desirable, overtaxation of capital income is not necessarily the ideal means to achieve it. Increased progressivity could also be achieved directly via tax rate adjustments without creating horizontal inequity between taxpayers receiving capital income and those receiving labor income. Cf. Durst, supra note 37, at 1286 ( $[A]$ policy of avoiding indexation of the tax base to enhance progressivity may be desirable within some range of possible inflation rates, but almost certainly will lead to excessive tax burdens on income from capital at higher rates.").

Lack of indexation can also be viewed as a form of wealth taxation. Although income has already been assumed as the proper tax base, see supra note 5 and accompanying text, lack of indexation would in any event be an undesirable proxy for a wealth tax because the variable nature of inflation would result in widely fluctuating tax burdens from year to year. See Martin J. Bailey, Inflationary Distortions and Taxes, in INFLATION AND THE INCOME TAX, supra note 2, at 291, 323 (comments of Peter Diamond) ("In the end . . . we are left with the simple fact that inflation results in a tax on wealth. A tax on wealth does not bother me, but its random size does.").

${ }^{69}$ See supra note 54 and accompanying text.

${ }^{70}$ See Stiglitz, supra note 1, at 444.

${ }^{71}$ See supra note 59 and accompanying text.

72 For a detailed discussion of the economic effects of taxing nominal interest income, see Bossons, supra note 1 , at 950-59.

${ }^{73}$ See id. at 957; Halperin \& Steuerle, supra note 1, at 358. 
of investment funds between debt and equity. ${ }^{74}$ In particular, high-bracket entities such as corporations will engage in more leveraged financing, which may increase business instability. ${ }^{75}$ Third, failure to permit taxpayers to recognize unanticipated inflationary gain or loss on debt for tax purposes increases the economic risks associated with debt, resulting in reduced levels of savings and investment. $^{76}$ Finally, any revenue loss created by lack of debt indexation must be recaptured by increased tax rates, which in turn increase the magnitude of these and other distortions throughout the tax system. ${ }^{77}$

\section{B. Revenue Effects}

While indexation of capital assets, depreciable assets, or inventories would necessarily produce a revenue loss, the revenue effect of debt indexation is not obvious because there are two sides to every debt transaction. Although debt indexation will reduce income for net creditors, it will also increase the income of net debtors by reducing their interest deductions. Thus, the overall revenue effect of debt indexation will depend on the marginal tax rates faced by debtors and creditors, the extent to which interest expenses are less than fully deductible, and the extent to which some debtors or creditors are exempted from debt indexation on political or administrative grounds. What follows is a brief discussion of the probable revenue effect of indexation with respect to various categories of debt.

Indexation of taxable government debt will be a revenue loser because most government debtors are tax exempt ${ }^{78}$ and will suffer no tax loss from the reduced interest deduction due to indexation. Creditors, meanwhile, will receive a tax benefit from excluding part of the nominal interest income received from the debt. However, this revenue loss will not occur with respect to government debt that is held by non-taxable entities such as pension funds. Also, this revenue loss will be tempered by the fact that partial exclusion of

74 See TREASURY I, supra note 59, at 194.

75 See Bossons, supra note 1, at 950, 957-58 \& n.28.

${ }^{76}$ See John Bossons, Reply, 30 WAYNE L. REV. 983, 986 (1984); TREASURY I, supra note 59, at 194.

77 See Bossons, supra note 1, at 950-51.

${ }^{78}$ See I.R.C. § 501(c)(1) (1988); see also MICHaEL D. ROSE \& JoHN C. Chommie, FEDERAL INCOME TAXATION \$11.03 (3d ed. 1988). 
interest income will permit the federal government to pay a lower interest rate on its debt. ${ }^{79}$

Assuming home mortgage debt is indexed for the creditor but not for the debtor, ${ }^{80}$ indexation of this type of debt will also produce a revenue loss. The magnitude of this revenue loss will depend on the marginal tax rates faced by home mortgage creditors. However, because the decision to exclude home mortgage debt from indexation is purely political, any resulting revenue loss should be viewed as a cost of subsidizing home ownership, rather than as a cost of debt indexation itself. Should Congress choose not to exempt home mortgage debt from indexation, the revenue effect of indexing it would depend on the relative tax rates experienced by home mortgage debtors and creditors. Although a large percentage of home mortgage debt is held by banks and savings and loan associations, ${ }^{81}$ these institutions ultimately borrow most of their funds from depositors. ${ }^{82}$ Assuming debt indexation is done properly, financial institutions would receive net indexation benefits only to the extent of their net equity. ${ }^{83}$ To the extent that home mortgage debt is ultimately financed through funds borrowed by financial institutions, the revenue effect from indexing home mortgage indebtedness will depend on depositors' marginal tax rates as well as those of financial institutions. However, even assuming that depositors, financial institutions, and other home mortgage lenders are all relatively high bracket taxpayers, a revenue loss from indexing home mortgage debt would be unlikely because most mortgage-holding homeowners are also in relatively high tax brackets.

Indexation of consumer debt will produce a revenue loss. Because most consumer interest is considered non-deductible personal interest, ${ }^{84}$ the revenue pickup from reduced interest

79 This result follows from the fact that, in general, nominal interest rates will be lower under a system of debt indexation. For a discussion of the revenue effects of indexing government debt, see Durst, supra note 37, at 1255-56.

${ }^{80}$ See infra notes 170-76 and accompanying text.

81 See U.S. LEAGUE OF SAV. INST., 87 SAVINGS INSTITUTIONS SOURCEBOOK 8 (1987) ("Savings institutions are the single major source of residential credit, [a]t year-end 1986 . . . [accounting] for $34.3 \%$ of all residential loans outstanding.").

${ }^{82}$ See id. 6 ("Saving deposits . . represent about $80 \%$ of all liabilities . . . .").

83 One of the major flaws in the Treasury $I$ debt indexation proposal was its improper treatment of financial institutions and other taxpayers who engaged in borrowing and lending activities at different interest rates. See infra note 92 and accompanying text.

${ }^{84}$ See I.R.C. \$ 163 (h) (1988). 
deductions will not fully offset the revenue loss from the interest income excluded by indexation. Like home mortgage debt, much consumer credit is provided by financial institutions. Therefore, the magnitude of the revenue loss from indexing consumer debt will also depend on the tax rates of financial institutions and their depositors as well as those of other providers of consumer credit.

Indexation of business debt should produce a revenue gain. On the creditors' side, business bank debt is subject to approximately the same revenue analysis as home mortgage debt and consumer credit. On the debtors' side, businesses are typically high-bracket taxpayers. ${ }^{85}$ Therefore the revenue gain from the partially excluded interest deduction should exceed the revenue loss from the corresponding excluded interest income. Corporate bonds should also produce a revenue pickup. Bond issuers are typically highbracket taxpayers, but a significant fraction of corporate bonds are held by tax exempt entities, ${ }^{86}$ reducing the revenue loss on the creditors' side.

Although it is difficult to predict the overall revenue effect of debt indexation, it seems unlikely to be a big revenue loser. ${ }^{87}$ The fact that the federal government is a net debtor will have the largest negative effect on revenue, although this effect will be tempered by lower interest rates on federal borrowing. On the other hand, present overtaxation of interest income relative to income from other capital means that net creditors, with the exception of financial institutions, are disproportionately low-bracket taxpayers, whereas net debtors are disproportionately high-bracket taxpayers. ${ }^{88}$ With respect to these creditors and debtors, debt indexation will produce a net revenue gain. Overall, any possible revenue loss from debt indexation should not be of sufficient magnitude to threaten the political feasibility of debt indexation.

${ }^{85}$ At least one recent study found that the effective corporate tax rate has been approximately $25 \%$ since the 1986 Tax Reform Act. See Forrest D. Marovelli \& Mark L. Starcher, Tax Reform is Working, According to New CTJ Study on Effective Corporate Tax Rates, 45 TAX NoTES 524 (1989).

${ }^{86}$ See Edward D. Kleinbard, Equity Derivative Products: Financial Innovation's Newest Challenge to the Tax System, 69 TEXAS L. REv. 1319, 1362 n.129 (1991).

${ }^{87}$ See Steuerle, supra note 1 , at 1007 (presenting 1981 data suggesting debt indexation would produce a substantial revenue gain under then-existing law).

${ }^{88}$ See supra note 59 and accompanying text. 


\section{Administrability Issues}

Commentators generally agree that indexation would make the tax system fairer and reduce economic distortions. ${ }^{89}$ Critics of indexation have instead tended to focus on the issue of administrability. ${ }^{90}$ Many partial indexation schemes have excluded debt indexation on this basis. ${ }^{91}$ Even Treasury I's proposal, although providing for debt indexation, made serious departures from theoretically correct indexation on the grounds of administrability. ${ }^{92}$ This Comment seeks to demonstrate the feasibility of accurate debt indexation by considering various general issues in the implementation of such a scheme, ${ }^{93}$ by proposing a suitable transition rule to deal with the problem of pre-existing debt, ${ }^{94}$ and by discussing how indexation could be administered for several specific classes of debt. ${ }^{95}$ In general, de minimis rules, new reporting requirements, and approximate methods of calculation should make the incremental administrative burden of debt indexation negligible for most taxpayers. ${ }^{96}$ Financial institutions

${ }^{89}$ See supra note 1.

${ }^{90}$ See supra note 2.

${ }^{91}$ See infra note 106 and accompanying text.

92 The Treasury I proposal rejected the theoretically correct approach of indexing debt based on principal balances because it was considered too complex. See TREASURY I, supra note 59, at 197; Durst, supra note 37, at 1254 n.125; Jonathan B. Forman, Treasury's Interest Indexing Proposal: Either a Bank or a Net Lender Be, 26 TAX NoTEs 856, 858 (1985). Instead, Treasury I adopted an approximate approach which based the indexation adjustment on interest rather than principal. Specifically, the Treasury I scheme assumed that the real pre-tax interest rate (including credit risk premium) on all debt was $6 \%$. Given the actual rate of inflation, it excluded a fraction of nominal interest from taxation based on this assumption. For example, if the rate of inflation were $4 \%$, Treasury I would have excluded $40 \%$ of all nominal interest from taxation $(40 \%=4 \% /(4 \%+6 \%))$. See TREASURY I, supra note 59 , at 194-97.

One of the more serious flaws of the Treasury I proposal was the inappropriate result it would have produced for financial institutions and other taxpayers who borrow money and then loan it at a higher interest rate. Such a taxpayer might have no net debt position, i.e. amount borrowed equals amount owed, and hence no actual inflationary loss. Yet, the Treasury I scheme would have incorrectly excluded a fraction of this taxpayer's net interest income, resulting in a potentially large reduction in taxable income. See Durst, supra note 37, at 1255 n.129 (noting that "Treasury I's rough method of interest indexation reached inappropriate results for those taxpayers ... engaged in . . . borrowing and relending money"); Forman, supra, at 859-60; Halperin \& Steuerle, supra note 1, at 369-70.

${ }^{93}$ See infra part III.

${ }^{94}$ See infra part IV.

95 See infra part V.

${ }^{96}$ See Bossons, supra note 1, at 965-66 (discussing the imposition of new reporting 
should be able to comply with these new reporting requirements at little expense and with no additional information from taxpayers. ${ }^{97}$ The only taxpayers likely to experience any significant administrative burden are those who engage in transactions that already require sophisticated tax treatment.

The issue of administrability ultimately enters the political arena entwined with issues of equity, efficiency, and revenue. When these other factors favor tax reform, Congress has been willing to impose tremendous complexity on taxpayers. ${ }^{98}$ Unfortunately, although Congress has recognized some of the problems resulting from the lack of indexation, it has thus far responded with ad hoc solutions such as the investment interest limitation, ${ }^{99}$ the at-risk rules, ${ }^{100}$ and the passive activity rules. ${ }^{101}$ These provisions add significant complexity to the Code without directly confronting the basic problem of income mismeasurement. ${ }^{102}$ Furthermore, their presence reduces the overall effect of this mismeasurement, making debt indexation less appealing in light of the effects that remain. An accurate appraisal of the administrative complexity of debt indexation must also consider the simplifying effect indexation

requirements and de minimis rules and noting that "[f]or most individuals and small businesses, indexation should, if properly implemented, impose virtually no calculation burden ${ }^{n}$ ).

${ }^{97}$ See id. at 966 ("For efficient financial institutions, the cost per account of modifying a computerized accounting system would be trivial."); Halperin \& Steuerle, supra note 1, at 359 (noting that in many cases, "individuals deal with financial institutions that have access to the technology to implement indexing without undue difficulty").

${ }^{98}$ Readers skeptical of this proposition are invited to consult the Code provisions for international taxation. The foreign tax credit limitation rules, see I.R.C. § 904 (1988), and the Subpart F rules, see $i d$. $\$ \S 951-964$, make the complexities of debt indexation appear relatively trivial.

${ }^{99}$ The investment interest limitation limits the current deductibility of interest expense on "indebtedness properly allocable to property held for investment" to the taxpayer's net investment income. Any interest expense not deductible in one taxable year as a result of the investment interest limitation is carried forward to the next taxable year. See id. § 163(d).

100 The at-risk rules limit taxpayers' losses in certain activities to the amount considered to be at-risk. Amount at-risk is defined to exclude certain forms of indebtedness. See id. $\$ 465$.

101 The passive activity rules limit the deductibility of interest allocable to passive activities by denying the deductibility of passive activity losses to the extent that they exceed passive activity income. See id. $\$ 469$.

102 See Jerome Kurtz, Comments on "Indexing for Inflation and the Interest Deduction", 30 WAYNE L. REV. 969, 970 (1984) (noting that the investment interest limitation only partially addresses the problem presented by the failure to tax inflationary gains and losses properly). 
would have on tax computation under existing law. Many taxpayers who are subject to the investment interest limitation, at-risk rules, and passive activity rules would find these provisions inapplicable under debt indexation due to their reduced interest deductions.

\section{General Issues in the IMPLEMENTAtion of DebT INDEXATION}

\section{A. Partial Versus Comprehensive Indexation}

A comprehensive solution to the inflation-induced inequities and distortions existing under current law requires indexation of capital assets, depreciable assets, and inventories, as well as indebtedness. ${ }^{103}$ Although there is widespread agreement on the desirability of such comprehensive indexation, substantial disagreement exists as to its administrability. ${ }^{104}$ While some proposals advocate comprehensive indexation, ${ }^{105}$ others argue that comprehensive indexation is impracticable, and advance, instead, a partial scheme. ${ }^{106}$ However, because of the tax arbitrage possibilities presented by partial indexation, ${ }^{107}$ tax base indexation may be an area where a workable partial solution is more difficult than a comprehensive one. ${ }^{108}$

Because of the political and administrative difficulties involved in adopting any form of indexation, the initial attempt to index the tax base for inflation may be a partial one. ${ }^{109}$ The usual assumption made by proponents of partial indexation is that debt indexation would present too many administrative difficulties and, therefore, should be excluded from any indexation scheme. Other portions of this Comment attempt to demonstrate that debt

${ }^{103}$ See supra note 14 and accompanying text.

${ }^{104}$ See supra notes 1-2 and accompanying text.

105 See, e.g., TREASURY I, supra note 59, at 151-72, 177-200 (presenting Treasury Department proposals to index debt, capital assets, depreciation allowances, and inventories).

106 See, e.g., Durst, supra note 37, at 1221 (proposing elective indexation of capital assets and depreciation allowances, and limiting indexation of debt-financed assets by requiring partial exclusion of interest expenses by those who elect to index).

${ }_{107}$ See infra notes 111-13 and accompanying text.

${ }^{108}$ See Bossons, supra note 1, at 961 ("[T] he key to easy implementation [of any form of tax base indexation] is comprehensive implementation for all assets and debts. If implementation is restricted in any way, it immediately becomes substantially more complex.").

${ }^{109}$ Cf. id. at 966-67 (" $[\mathrm{B}]$ ecause of the high economic cost of the inflation induced tax distortions, it may be worthwhile to introduce limited tax indexation initiatives before proceeding to attempt to implement more comprehensive reform."). 
indexation should not be rejected on administrative grounds. ${ }^{110}$ Additionally, indexing capital assets, depreciation allowances, or inventories without indexing debt would exacerbate existing arbitrage opportunities for purchasers of debt-financed assets. ${ }^{111}$ Any partial scheme that excluded debt indexation would need some ad hoc solution to this enhanced opportunity for arbitrage. ${ }^{112}$ Even if indexing debt does involve some additional administrative complexity, indexing debt in conjunction with other assets would not involve significantly more complexity than implementation of an adequate ad hoc solution to this enhanced opportunity for tax arbitrage. ${ }^{113}$ Administrative issues aside, because the taxation of capital assets, depreciable assets, and inventories each include some

110 See infra parts IV \& V.

111 See Bossons, supra note 1, at 967; Durst, supra note 37, at 1276-77; New York State Bar Ass'n, Report on Inflation Adjustments to the Basis of Capital Assets, 48 TAX Notes 759, 762 (1990) [hereinafter NYSBA Report].

112 Partial indexation would encourage taxpayers to borrow money to purchase indexed assets. Nominal interest expense on the borrowed funds would be fully deductible while nominal income on the indexed assets would be partially excluded from taxation. This would enable taxpayers to create a net tax loss without suffering any true economic loss.

113 The capital asset indexation provision passed by the House of Representatives as part of the Omnibus Budget Reconciliation Act of 1989 (but not included in the final legislation) attempted to limit debt arbitrage opportunities by excluding all gain from the sale or disposition of an indexed asset from $\S 163(d)$ investment income, see I.R.C. $\$ 163$ (d) (1988), and by allowing indexation only in computing gain. See H.R. 3299, 101st Cong., 1st Sess. $\$ 11961$ (1989). The investment income limitation is problematic because it does not attack debt arbitrage by taxpayers whose interest expense is treated as business or passive-activity interest or by taxpayers who have enough investment income from other sources to offset all of their investment interest expense. The limitation of indexation to transactions involving gain would produce horizontal inequities as some taxpayers suffering inflationary losses on nondebt-financed assets would be denied an indexation adjustment. It would also enhance the lock-in effect. See NYSBA Report, supra note 111, at 764. The NYSBA Report noted that debt tracing or debt allocation rules could prevent debt arbitrage but rejected such rules as too complex. See id. at 764-65; see also Bossons, supra note 1, at 946 ("In some respects, a limited indexation scheme [excluding debt indexation] is harder to implement than a comprehensive approach, primarily because of the additional requirements for debt tracing that arise from the non-neutralities inherent in a limited scheme.").

Another proposal intended to limit tax arbitrage by holders of debt-financed assets would permit taxpayers to elect indexation of depreciation allowances and capital gains only if they agreed to forgo a fraction of their interest deductions. See Durst, supra note 37, at 1277-84. This approach has the benefit of making the inflation-related adjustment to interest deductions elective, eliminating any additional complexity for taxpayers who elected not to index their depreciation allowances and capital assets. However, it offers no administrative advantage over true debt indexation for taxpayers who do elect to index depreciation allowances and capital assets. 
form of tax preference that partially offsets the failure to index these assets, lack of debt indexation creates the greatest inequities and distortions, and is, therefore, most in need of remediation. ${ }^{114}$ For these reasons, debt indexation should be included in any partial indexation scheme.

\section{B. Recognition of the Inflation Adjustment}

The timing of recognition of the inflation adjustment is a vital issue in the implementation of any scheme of debt indexation. One possibility is to adjust the basis of debt annually by the amount of any inflationary gain or loss. This scheme would defer recognition of the inflation adjustment until other gain or loss on the debt is recognized through sale, exchange, or retirement. The alternative is to recognize inflationary gain and loss currently by reducing the amount of interest income or expense recognized over the term of the debt. Our present treatment of gain and loss in the market value of debt is a hybrid of current and deferred taxation. The basis-adjustment approach for recognizing inflationary gain and loss is analogous to the deferred taxation of unanticipated gain or loss in the market value of debt imposed by the realization requirement. ${ }^{115}$ The interest-adjustment approach is analogous to the current accrual-type taxation applied to most forms of anticipated gain or loss in the market value of debt. ${ }^{116}$

Over the life of a debt, the cumulative inflation adjustment should be based on actual inflation just as overall taxation of income from a debt is based on actual rather than anticipated gain or loss. ${ }^{117}$ During the term of a debt, however, the Code general-

114 See supra parts II.A \& II.B.

${ }^{115}$ See I.R.C. \$ 1001(c) (1988).

${ }^{116}$ See, e.g., id. §§ 163(e), $1271-1275$ (imposing approximate accrual taxation on anticipated gain or loss on original issue discount obligations); id. $\S 171$ (permitting taxpayers to elect amortization of certain bond premiums); id. $\$ 1286$ (imposing original issue discount rules on stripped bonds). In effect, these provisions each permit or require anticipated gain or loss on debt to be recognized annually. One case in which accrual of anticipated gain is not imposed is market discount bonds. Instead of requiring accrual, the Code attacks the problem of tax deferral by partially deferring direct interest expenses incurred to carry a market discount bond. See id. $\S 1277$.

${ }^{117}$ See Bossons, supra note 76, at 986-88. But see Michael J. McIntyre, Comments on "Indexing for Inflation and the Interest Deduction", 30 WAYNE L. REV. 973, 980-81 (1984) (claiming that indexation should adjust for anticipated inflation but not for unanticipated inflation). 
ly bases taxation on expected income. ${ }^{118}$ Consistency with this general principle would support current realization of an adjustment for anticipated inflation and deferral of any adjustment for unanticipated inflation. There are, however, two reasons that anticipated and unanticipated inflation should not be accounted for separately. First, to calculate an inflation adjustment based on anticipated inflation, it would be necessary to know the anticipated rate of inflation underlying each debt. This is clearly infeasible, ${ }^{119}$ although some standard rate of anticipated inflation might be assumed to underlie all debt without too much loss of accuracy. Second, treating anticipated and unanticipated inflation differently would unnecessarily increase complexity by requiring both annual interest adjustments and cumulative basis adjustments upon realization. ${ }^{120}$

Assuming a single inflation adjustment will be made based on actual inflation, a choice must still be made between basis-adjustment and interest-adjustment. There are several arguments that favor the use of an interest-adjustment over a basis-adjustment. First, it is the interest payment that contains an anticipated-inflation component to compensate the creditor for the inflationary loss in the real value of his principal. Regardless of when the interest payment actually occurs, anticipated interest income and expense are generally recognized annually. ${ }^{121}$ Indexing interest will more closely reflect true economic income for each tax period by offsetting the anticipated-inflation component of interest as it is recognized. ${ }^{122}$ Indexing basis rather than interest would result in large, artificial fluctuations in income as inflation adjustments accrued over a long period are recognized in a single year. Second,

\footnotetext{
118 See supra note 116 and accompanying text.

${ }^{119}$ See Bossons, supra note 76, at 988; Halperin \& Steuerle, supra note 1, at 36768; Hickman, supra note 53, at 801 .

${ }_{120}$ See Halperin \& Steuerle, supra note 1, at 366-68.

121 See supra note 116 and accompanying text.

122 Theoretically, the distinction between assets that should be indexed annually and those that should be indexed only upon a normal recognition event should be based on the distinction between assets that rise in value with inflation and assets that do not. This distinction is not achieved simply by differentiating between non-debt and debt. Nonconvertible, nonparticipating preferred stock is an example of a nondebt asset whose value does not increase with inflation, while convertible bonds and bonds with equity kickers are good examples of debt that do appreciate with inflation. See Halperin \& Steuerle, supra note 1, at 364-66. Some arbitrariness in distinguishing between assets that should be indexed currently and those whose indexation adjustment should be deferred is inevitable under a realization-based system. Furthermore, this problem is not unique to indexation. See id. at 362-64.
} 
basis-adjustment would impose large, one-time tax liabilities on debtors as inflation adjustments cumulated over the term of a debt are finally recognized upon disposition. Unlike the large tax liabilities often recognized on the sale of capital assets, which can usually be satisfied with sale proceeds, these indexation liabilities would become due at the same time that debtors are supposed to satisfy their debt liabilities. Insolvent debtors would be unable to satisfy their indexation-based tax liabilities, ${ }^{123}$ while their creditors would presumably still be permitted tax deductions for their corresponding inflationary losses. This would result in an unnecessary revenue loss. Finally, considering a broad range of debt, interest-adjustment would be easier to administer. Basis-adjustment would be somewhat simpler where the principal balance remains constant over the duration of a debt because the entire inflation adjustment could be calculated once, upon realization, rather than annually. On the other hand, interest-adjustment is simpler where principal is paid over the term of a debt, as with self-amortizing loans or lines of credit. Basis-adjustment would require the taxpayer to account separately for indexed basis and unpaid principal. Under the interest-adjustment approach, basis is simply equal unpaid principal for most debt.

In addition to these arguments supporting the use of an interestadjustment, the usual reasons supporting realization-based taxation are diminished or nonexistent in the context of debt indexation. The primary reason that changes in the market value of many assets are not recognized until realization is that annual recognition would create problems of valuation and liquidity. ${ }^{124}$ Valuation problems would arise because of the difficulty of obtaining accurate assessments of the worth of an asset in the absence of a market transaction. Liquidity problems would arise because holders of indivisible assets would be taxed on unrealized gains and might, therefore, be forced to sell their assets prematurely to meet this tax liability. Similarly, holders of divisible assets might be forced to incur large transaction costs in subdividing their assets for partial sale. Although these asset-holders might be able to satisfy their tax

${ }^{123}$ Although $\S 6331$ of the Code, see I.R.C. $\$ 6331$ (1988), authorizes the Secretary to collect tax deficiencies by levy, the available property may be exempt from levy under $\S 6334$, see id. $\$ 6334$, or may be of insufficient value to satisfy the tax liability.

${ }^{124}$ See David J. Shakow, Taxation Without Realization: A Proposal for Accrual Taxation, 134 U. PA. L. REV. 1111, 1118 (1986); Mark L. Louie, Note, Realizing Appreciation Without Sale: Accrual Taxation of Capital Gains on Marketable Securities, 34 STAN. L. REV. 857, 865-67 (1982). 
liabilities by borrowing money secured by their appreciated assets, many would not have access to low-cost credit.

In the context of debt indexation, neither of these problems strongly support deferral of the inflation adjustment. ${ }^{125}$ Under an interest-adjustment approach, valuation will not present a problem because the inflation adjustment will be calculated from the taxpayer's basis rather than from the market value of debt ${ }^{126}$ and no annual valuation will be required. Liquidity is also less problematic in the context of debt indexation than with other capital assets. To the extent that some debtors face increased tax liabilities as the result of recognizing inflation adjustments annually, these debtors can presumably issue additional debt to finance this tax liability. They should have no difficulty securing this additional debt because the very inflation that created the need for additional borrowing will also have reduced the real value of their pre-existing debt.

Assuming that the choice is made to adjust interest annually on the basis of actual inflation, an administrative problem may arise if the inflation adjustment exceeds the amount of nominal interest. In this case, it is clear that the debtor should not recognize any interest expense, and the creditor should not recognize any interest income. The best treatment of the excess inflation adjustment above nominal interest is less obvious. Theoretically, the creditor could simply recognize a current loss in the amount of the excess inflation adjustment, with the debtor recognizing a corresponding gain. This scheme, however, would require revisions in interest reporting requirements and special rules making the debtor's recognition of gain from excess inflation mandatory. ${ }^{127}$ An alternative rule would require any excess inflation adjustment to be carried forward to later years, with any unused adjustment to be recognized upon disposition or termination of the debt.

${ }^{125}$ See T. Nicolaus Tideman \& Donald P. Tucker, The Tax Treatment of Business Profits under Inflationary Conditions, in INFLATION AND THE INCOME TAX, supra note 2, at 33, 58 (remarking that " $[t]$ he . . . major arguments for deferring the tax on capital gains until realization do not apply to inflation-related gains on monetary liabilities").

${ }^{126}$ See infra notes $184-85$ and accompanying text.

127 See McIntyre, supra note 117, at 981 (rejecting this approach on the grounds that "taxpayers cannot be expected to report negative deductions"). 


\section{Measuring Inflation}

Any attempt to index the tax system for the effects of inflation must decide how to measure inflation. Inflation affects the tax system in two ways. First, inflation changes the rate structure of the income tax by changing the real value of all nominal dollar amounts in the Code. ${ }^{128}$ Many of these amounts are already indexed to increases in the Consumer Price Index. ${ }^{129}$ Second, inflation distorts the tax base by artificially increasing taxpayers' nominal income. ${ }^{130}$ This tax base distortion affects not only debt, but also capital assets, depreciation allowances, and inventories. ${ }^{181}$ At present, none of these areas are explicitly indexed and theoretically, different measures of inflation could be adopted for indexing each of them. ${ }^{132}$ However, using the same index for each of these areas would be desirable both on grounds of administrative ease and maintenance of neutrality in the taxation of debt-financed assets between inflationary and non-inflationary conditions. ${ }^{133}$

Discussion of the merits of using various measures of inflation is beyond the scope of this Comment. Assuming the use of some broad-based inflation index, however, the actual choice of index is of limited significance. ${ }^{134}$ Because the Consumer Price Index is already used to index nominal dollar figures throughout the Code, it is a likely candidate for debt indexation. In any event, the implementation of tax base indexation, whether for debt or for other assets, should not be rejected on the basis of measurement problems. ${ }^{135}$

${ }^{128}$ See supra note 10 and accompanying text.

${ }^{129}$ See, e.g., I.R.C. § I(f) (1988) (indexing tax brackets); id. § 32(i) (indexing earned income credit); $i d$. $\$ 41(e)(5)$ (indexing research and development credit); id. \$ 63(c)(4) (indexing standard deduction and additional deduction for the blind and aged); $i d$. \$ 151(d)(4) (West Supp. 1991) (indexing personal exemption amount and phaseout threshold).

${ }^{130}$ See supra note 12 and accompanying text.

131 See supra note 14 and accompanying text.

132 See Aaron, supra note 2, at 15-16. Furthermore, the choice of an inflation index for tax base indexation need not be the same as that made for rate structure indexation. See Edward F. Denison, Price Series for Indexing the Income Tax System, in INFLATION AND THE INCOME TAX, supra note 2, at 233, 235-36 ("The measurement of income in current prices when inflation occurs [i.e. tax base indexation] is unrelated to [tax bracket] indexing, and the conclusions [about the appropriate choice of index] should not be extended to it.").

193 See Aaron, supra note 2, at 14-15.

134 See Bossons, supra note 1 , at 960 n.31.

${ }^{135}$ Assuming that income is chosen as a tax base because it is supposed to represent welfare or ability to pay, it is clear that income measured in monetary terms 


\section{Distinguishing Debt from Other Assets and Liabilities}

One threat to the efficacy of debt indexation is the possibility that debtors might be able to circumvent the reduced interest deductions resulting from debt indexation by restructuring their loan transactions as rental transactions. ${ }^{136}$ In an efficient market, the rental payment for a piece of property will approximate the interest expense on debt sufficient to purchase that property plus the anticipated appreciation or depreciation in property value over the term of the lease. ${ }^{137}$ Rather than debt-financing a purchase, a high-bracket taxpayer would realize a tax savings through leasefinancing. ${ }^{138}$ His rental payment would then be fully deductible, whereas, in the case of debt financing, his interest expense would have been reduced by indexation.

If debt indexation is undertaken as part of a comprehensive plan that also includes the indexation of capital assets and depreciation allowances, the extent of this lease financing problem will be greatly reduced. In this case, the advantage obtained by renting will be offset by the disadvantage of not indexing the rental property's basis. ${ }^{139}$ Even absent comprehensive tax base indexation, preferential tax treatment of capital and depreciable assets will function as a form of ad hoc indexation that will reduce the value of leasefinancing for high-bracket taxpayers. If this ad hoc indexation were

is not a perfect proxy for individual welfare. $C f$. Denison, supra note 132, at 236-37 (noting that tax law ignores geographical price differences even though they are related to welfare). This same problem also prevents any single inflation index from being a perfect measure of the effect of inflation on all taxpayers. The existence of this problem has not prevented the taxation of income in nominal monetary terms; likewise, it should not prevent tax base indexation. Cf. Bossons, supra note 1 , at 960 $61 \mathrm{n} .31$ ("The differences resulting from the choice of index are of second-order importance compared to the effect of using any general price index to correct taxable income."). But see NYSBA Report, supra note 111, at 773 (citing the fact that "the use of any particular inflation index will offer inexact relief to the owner of any particular

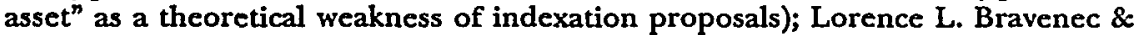
Anthony P. Curatola, Indexing the Federal Tax System for Inflation, 28 TAX NoTES 457, 458 (1985) (arguing that use of the Consumer Price Index "will misstate the effect of inflation on business and investment assets").

${ }^{136}$ See McIntyre, supra note 117 , at 979-80.

${ }^{137}$ See Bossons, supra note 76, at 984 . The costs of risk reallocation and tax complications will cause rental prices to diverge somewhat from this ideal.

${ }^{138}$ The lessor would presumably be a low-bracket taxpayer who purchased the leased asset using debt financing, for whom the reduced interest deduction would be much less costly.

${ }^{139}$ See McIntyre, supra note 117 , at 980 (discussing the offsetting effects of debt indexation and indexation of depreciation allowances). 
considered insufficient, it might be necessary to include lease financing as a form of indexable debt. ${ }^{140}$

One secondary benefit of debt indexation is that it will reduce the importance of the distinction between corporate debt and equity. Because interest payments are fully deductible and dividend payments are not deductible at all, corporations are strongly encouraged to characterize capital contributions as debt rather than equity. ${ }^{141}$ This has resulted in substantial litigation as the Internal Revenue Service has sought to challenge taxpayers' characterizations. In 1969, Congress granted the Treasury authority to promulgate regulations governing the determination of whether an interest in a corporation would be treated as debt or equity. ${ }^{142}$ But more than twenty years later, final regulations have yet to be issued. Because debt indexation will decrease the magnitude of the corporate interest deduction, ${ }^{143}$ it will reduce the corporate incentive to recharacterize capital contributions as debt.

\section{TRANSITION RULES}

Even tax law revisions that apply new rules only after the date of enactment can have major retroactive effects. These effects usually consist of market-driven changes in the value of assets and liabilities that were acquired before the revision, under the expectation that they would be taxed based on existing law. ${ }^{144}$

${ }^{140}$ See Bossons, supra note 76, at 985 . The lease/loan distinction presents other tax problems even in the absence of inflation. In particular, the typical level-rent lease includes a hidden loan element. Present taxation of nominal rental income and expense defers the lessee's income and the lessor's deductions. Proper taxation of leases requires separating rental payments into their depreciation and interest components. See George Mundstock, The Mistaxation of Rent: Eliminating the Lease/Loan Distinction, 53 TAX NoTES 353, 353 (1991). Applying an indexation adjustment to reduce the deductibility of the interest component of rental payments would eliminate any additional lease-financing incentive created by debt indexation. See, Bossons, supra note 76, at 986 (advocating an indexation adjustment for rental payments calculated by multiplying the inflation rate by the capitalized value of all future lease payments).

${ }^{141}$ See William T. Plumb, Jr., The Federal Income Tax Significance of Corporate Debt: A Critical Analysis and a Proposal, 26 TAX L. REv. 369, 371 (1971) (noting that "the tax consequences of debt are generally more favorable than those of stock").

142 See I.R.C. \$ 385 (1988).

143 Indexing will also decrease the interest income of holders of corporate debt. This benefit could potentially offset the disadvantage of indexing to the corporation. However, assuming holders of corporate debt tend to face lower tax rates than corporate lenders, see supra notes 85-86 and accompanying text, this offset would only be partial.

${ }^{144}$ See Michael J. Graetz, Legal Transitions: The Case of Retroactivity in Income Tax 
The major economic consequence of adopting debt indexation would be to lower the nominal interest rate on new debt. The interest rate would be lowered because it would no longer need to compensate the creditor for his tax liability on the anticipatedinflation component of his interest income. ${ }^{145}$ If debt indexation were applied to all debt outstanding after the date of enactment, the present value of existing, fixed-rate debt would increase as the effective yield on this pre-existing debt declined to match that of new debt. As with any drop in market interest rates, pre-existing, long-term debt would experience the greatest increase in value, while short-term debt would experience smaller increases.

These price changes in the value of pre-existing fixed-rate debt would result in windfall gains for creditors and windfall losses for debtors. ${ }^{146}$ Such windfalls are generally considered unfair and inefficient, and special transition rules are frequently adopted to limit windfall gains and losses resulting from tax law revisions. ${ }^{147}$ The following example demonstrates the windfall effects of implementing debt indexation in the absence of any transition scheme for pre-existing fixed-rate debt.

Example 4: $C$ agrees to lend $D$ the sum of $\$ 100.00$ for a period of one year. $\mathrm{C}$ and $\mathrm{D}$ both anticipate an inflation rate of $5 \%$. $\mathrm{G}$ is willing to accept, and $\mathrm{D}$ is willing to pay, an anticipated, real pretax interest rate of $2 \%$. C anticipates facing a marginal tax rate of $10 \%$, and $\mathrm{D}$ anticipates facing a marginal tax rate of $50 \%$. C and $D$ agree on a nominal interest rate of $9 \%$. Debt indexation is then enacted without any transition rule for pre-existing debt. The actual inflation rate for the period of the loan is $5 \%$.

As previously discussed, although $C$ and $D$ were willing to contract for a real pre-tax interest rate of $2 \%$, without debt indexation they were able to agree upon a nominal interest rate of $9 \%$, which would yield $C$ a real pre-tax interest rate of $3.44 \%$, and would charge $D$ a real pre-tax interest rate of $-1 \%{ }^{148}$ If this debt is then subjected to an inflation adjustment based on a $5 \%$ rate of actual inflation, $\$ 5.00$ of the $\$ 9.00$ nominal interest will be excluded

Revision, 126 U. PA. L. REV. 47, 49-52 (1977).

145 Compare the interest rate formula under debt indexation, supra text accompanying note 21 , with the formula under full taxation of nominal interest income, supra text accompanying note 29.

146 See Bossons, supra note 1, at 960-61.

147 See generally Graetz, supra note 144, at 63-87 (discussing efficiency and fairness issues relating to choice of transition rules).

${ }^{148}$ See supra notes 44-51 and accompanying text. 
from taxation. $C$ will be left with real pre-tax income of $\$ 4.00$, for a real pre-tax yield of $4 \%$. $D$ will receive a tax deduction of $\$ 4.00$, resulting in a real pre-tax interest rate of $4 \%$. Indexing debt will force $C$ and $D$ to face the same pre-tax interest rate, eliminating the taxpayer benefit usually created by the taxation of full nominal interest. $^{149}$ Unfortunately for $D$, this interest rate is $4 \%$ rather than the $2 \%$ that $C$ and $D$ were originally willing to accept. Indexation has produced a windfall gain for $C$-an increase in his effective, pre-tax interest rate from $3.44 \%$ to $4 \%$. Moreover, indexation has produced an even larger windfall loss for $D$-an increase in his effective, pre-tax interest rate from $-1 \%$ to $4 \% .{ }^{150}$

The primary function of a transition rule for debt indexation is to eliminate these windfall gains and losses on pre-existing, fixedrate debt. The success of any particular transition scheme must be measured, at least in part, by its ability to minimize these windfalls. There is a second important criterion, however, that any successful transition rule for debt indexation must also satisfy. The goal of any tax law revision is, very simply, to revise the law. Under the present system of nominal taxation of debt, parties can face real pre-tax interest rates that vary substantially from one another, and from the interest rate they would have agreed upon had they known that debt indexation would be in effect. ${ }^{151}$ The primary goal of debt indexation is to force all taxpayers to face the same real pre-tax interest rate, regardless of their marginal tax bracket. A successful transition scheme must not unduly impede this goal by delaying or diminishing the desirable effects of debt indexation. Thus, a successful transition rule must also force taxpayers to face the same real pre-tax interest rate on pre-existing debt that they would have faced had they known that debt indexation would be enacted and applied to their debt. ${ }^{152}$

${ }^{149}$ See supra notes 44-52 and accompanying text.

150 Arguably, the increase in the effective interest rate from $-1.00 \%$ to $2.00 \%$ is not a windfall loss, because $D$ was willing to face a pre-tax interest rate of $2.00 \%$. $D$ faced a rate of $-1.00 \%$ due only to the lack of debt indexation. Thus, a successful transition rule should not require $D$ to face an interest rate above $2.00 \%$, but it need not permit him to face an interest rate below $2.00 \%$.

${ }_{151}$ In Example 4, $C$ faced a real, pre-tax interest rate of $3.44 \%$, while $D$ 's rate was $1.00 \%$. Had the parties correctly anticipated that their debt would be indexed for inflation, they would have agreed to a rate of $2.00 \%$. See supra note 148 and accompanying text.

152 Thus, in Example 4, an ideal transition rule would require both $C$ and $D$ to face effective, pre-tax interest rates of $2 \%$, because this is the rate they would have agreed upon had debt indexation been in effect at the time the debt was incurred. 
Tax law revisions employ a variety of different transition schemes. In a seminal article on legal transitions, Professor Graetz discusses several general types of transition rules. ${ }^{153}$ This Comment will consider the applicability of the most important of these categories-delayed effective dates, phased-in effective dates, grandfathered effective dates, and holder-only grandfathered effective dates-to the problem of designing a transition rule for debt indexation. As will be seen, each of these rules fails to satisfy one or more of the criteria required of a successful transition scheme, namely, eliminating windfall gains and losses, and eliminating the undesirable effects of nominal taxation of debt.

Under a delayed effective date rule, a debt indexation provision would be enacted but would only become operative some number of years in the future. Such a rule would eliminate price changes in short-term debt that expired before the effective date, and would reduce price changes in longer-term debt. Assuming a typical delay of one or two years, however, the price effect of indexation on longterm debt would not be substantially reduced. ${ }^{154}$ Furthermore, delaying the effective date would entail forgoing the benefits of debt indexation for another few years.

Similar to the delayed effective date is the phased-in effective date. Rather than making debt indexation fully effective in a single year, under a phased-in effective date there would be a period of years during which the indexation adjustment would be made effective in increasingly larger percentages. ${ }^{155}$ Unfortunately, phased-in effective dates suffer from the same flaws as delayed effective dates-they do not fully eliminate price changes, because some portion of indexation on pre-existing long-term debt is phased-in, and they partially forgo the benefits of debt indexation for a period beyond the enactment date. ${ }^{156}$

See supra note 148 and accompanying text.

${ }^{153}$ See generally Graetz, supra note 144, at 52-63 (describing various types of effective date provisions and discussing their economic effects).

154 To significantly reduce the price effect of indexation on long-term debt, the delay would have to approach the term of such debt, which is frequently as long as 30 years. If debt indexation is considered a desirable reform, however, then any transition rule that would delay its implementation for such a length of time must be rejected.

155 For a time, the Treasury intended to delay the effective date of its debt indexation proposal from 1985 until 1989 and to phase it in at a rate of $10 \%$ per year. See Treasury Announces Modified Effective Dates and Transition Rules for Tax Reform Proposals, 26 TAX NOTES 866 (1985).

${ }^{156}$ On the other hand, both delayed and phased-in effective dates do avoid the 
Under a grandfathered effective date rule, all debt existing at the enactment date would be permanently exempted from indexation, while all new debt would be fully subject to indexation. Such a rule might appear to eliminate all undesirable price changes. This view ignores the fact that debtors tend to be in a higher marginal tax bracket than creditors. ${ }^{157}$ As the supply of old debt dwindles, the lowest-bracket creditors and the highest-bracket debtors would become willing to pay an increasing premium for any remaining unindexed debt and would acquire such debt from taxpayers closer to the breakeven marginal rate. Although it is unclear exactly how this premium would be split between buyers and sellers of grandfathered debt, grandfathering would produce windfall gains for holders of existing debt able to sell such debt at a premium. ${ }^{158}$ One way to avoid these windfalls would be to adopt a "holder-only" grandfathering rule. Under such a rule, pre-existing debt would be exempt from indexation only if it were possessed by the same taxpayer who held it as of the enactment date. Although holderonly grandfathering would eliminate price changes in pre-existing

need to develop rules to distinguish pre-existing debt from new debt-rules that could potentially complicate the implementation of any transition scheme for debt indexation. For this reason, John Bossons advocates an allowance rule which is quite similar to a phased-in effective date rule. Under an allowance rule, taxpayers would be permitted a full deduction of nominal interest on an amount of debt not exceeding an "allowed debt limit." This limit would be set to the amount of the taxpayer's outstanding debt at the culmination of debt indexation, and would be phased out at a rate of $5 \%$ per annum. See Bossons, supra note 1, at 962 . Likewise, interest-bearing assets would be subject to indexation only to the extent that they exceed this allowed debt limit. See id. at 963.

Bossons' approach not only avoids the need to develop rules distinguishing preexisting debt from new debt but also "has the advantage of making the tax system [relatively] neutral in its impact on most decisions regarding the use of debt." Id. at 962. This would occur because "[f]or most taxpayers, the debt financing decision would involve choices between alternative levels of debt which were all in excess of the allowable debt limit," meaning that most new financing decisions would involve the choice of indexed rather than unindexed debt. Id. Neither the delayed effective date rule nor the phased-in effective date rule make the tax system neutral in this way. Bossons' approach, however, would still result in price changes for pre-existing debt and would perpetuate some of the distortions associated with unindexed treatment of debt for years to come. See id. at 966 (noting that the disadvantage in the allowance approach is that it will still "provide a tax incentive to maintain debt/ equity ratios at levels which in some cases may be higher than they would be in a fully indexed world" because "the existing tax incentive to use debt financing . . . is only eliminated to the extent to which normal debt levels would be above ... the 'old' debt limit").

${ }^{157}$ See supra note 59 and accompanying text.

${ }^{158}$ Cf. Graetz, supra note 144, at 61 (describing similar effect where tax exemption on certain bonds is eliminated but exemption on pre-existing bonds is grandfathered). 
debt, it would do so at the cost of liquidity. More importantly, both normal and holder-only grandfathering would perpetuate some of the detrimental effects of non-indexation until all pre-existing debt had expired. Under either form of grandfathering, both highbracket debtors and low-bracket creditors would be able to enjoy the tax advantages of pre-existing, unindexed debt for many years beyond the enactment of indexation. Such a result is incompatible with the criterion that the beneficial effects of indexation should not be unduly delayed.

Because none of these common transition schemes seems completely adequate, it is time to consider whether a more satisfactory transition rule can be developed. As previously discussed, an ideal transition rule would require debtors and creditors to face the same effective pre-tax interest rate regardless of their marginal tax brackets, without creating the windfall gains and losses that would result from fully indexing pre-existing fixedrate debt. ${ }^{159}$ Without debt indexation, market interest rates will include a component, $i_{\text {tax }}$, that represents the tax on the anticipated inflation component of interest for a taxpayer at some breakeven marginal rate. ${ }^{160}$ An ideal transition rule would index preexisting fixed-rate debt but would give the debtor a tax credit equal to $i_{\text {tax }}$ times his indexable basis and give the debtor a tax surcharge in the same amount. Such a rule would effectively retransfer the tax-on-anticipated-inflation component of interest on pre-existing debt from the creditor back to the debtor, this component no longer being necessary where debt is indexed for inflation. After this credit/surcharge has been applied, creditor and debtor will still be facing the same effective, pre-tax interest rate but this rate will now equal the rate that they would have agreed upon had they known that their debt would be indexed. In order to achieve the correct adjustment, this tax-on-anticipated-inflation component, although transferred from the debtor to the creditor as interest, should be neither deductible nor includable in income, because it is ultimately retransferred via this tax credit/surcharge. This treatment could be accomplished by including the amount of the tax credit/surcharge as part of the inflation adjustment to be excluded in calculating taxable interest from nominal interest. ${ }^{161}$ The

${ }^{159}$ See supra notes $151-52$ and accompanying text.

$160 i_{\text {tax }}=i_{a} \times t^{*} /\left[1-t^{*}\right]$, where $i_{a}$ is the anticipated rate of inflation and $t^{*}$ is the breakeven marginal tax rate. See supra notes 29 \& 54 and accompanying text.

161 This proposed rule is conceptually similar to an approach Graetz terms the 
following example demonstrates the mechanics of this proposed transition rule, assuming anticipated inflation of $5 \%$ and a breakeven marginal tax rate of $25 \%$.

Example 4A: The facts are identical to those in Example 4, except that the proposed transition scheme applies to the pre-existing fixed-rate debt between $C$ and $D$.

As a result of the proposed transition rule, $C$ is subject to a tax surcharge of $1.67 \% \%^{162}$ on his indexable basis of $\$ 100.00$. Of the $\$ 9.00$ of nominal interest income, $\$ 5.00$ compensates $C$ for actual inflation, and $\$ 1.67$ is paid as a tax surcharge. $C$ therefore receives a real pre-tax return of $\$ 2.33$, for a real pre-tax yield of $2.33 \%$. $D$ likewise has a real pre-tax expense of $\$ 2.33$, for a real pre-tax interest rate of $2.33 \%$. This result is much closer to the $2 \%$ real interest rate to which the parties would have agreed had they known that their debt would be subject to indexation. ${ }^{163}$

This proposed rule does present some administrative difficulties. The variable $i_{t a x}$ is dependent on the breakeven marginal tax rate for debt and the anticipated rate of inflation. ${ }^{164}$ One problem is that both the breakeven marginal tax rate and the anticipated rate of inflation have varied over time. This difficulty could be eliminated by requiring the percentage of the tax credit/surcharge to be obtained from a historical table. This table could be constructed from breakeven tax rates and anticipated inflation rates existing when the debt was originally incurred. Measurement problems involved in determining these variables, however, would make them imprecise, so such a scheme would probably be considered too complex to justify the limited increase in accuracy it would produce. ${ }^{165}$

"phased-out grandfather rule." See Graetz, supra note 144, at 63 n.53.

$1620.0167=0.05 \times 0.25 /(1-0.25)$. See supra note 159 and accompanying text.

163 If the rate of anticipated inflation and the breakeven marginal tax rate used to calculate the tax credit/surcharge rate exactly equal the anticipated inflation rate and breakeven marginal tax rate underlying the particular loan, then the real pre-tax interest rate will be corrected to exactly the rate that the parties would have agreed to had they known that their debt would be subject to indexation.

164 See supra note 159.

165 To the extent that tax rates and the rate of anticipated inflation have declined since the late 1970 s and early 1980 s, the average magnitude of the transition windfalls produced by assuming a single breakeven tax rate and anticipated rate of inflation for all debt will also be reduced. Assuming that the existence of transition windfalls is one impediment to the adoption of debt indexation, it would be better to implement debt indexation now rather than in a future climate of higher inflation and increased tax rates. 
A second difficulty arises from the fact that both the breakeven tax rate and the rate of anticipated inflation are market variables. The interest rate on any particular debt may have been based on the anticipated marginal tax rates of a specific creditor and debtor and on the rate of inflation anticipated by these parties. Any transition scheme based on these subjective values would clearly be unadministrable, so it is necessary to assume that these subjective values are reasonably close to the corresponding market variables. This assumption is plausible because an efficient debt market would preclude either the creditor or the debtor from entering into any transaction based on subjective values that differed substantially from corresponding market variables.

Given these considerations, a hypothetical transition rule might assume anticipated inflation of $5 \%$ and a breakeven marginal tax rate of $25 \%$, resulting in a $1.67 \%$ credit/surcharge rate. ${ }^{166}$ Legislation enacting debt indexation could make it fully effective at the beginning of the following year. ${ }^{167}$ After that date, all debt would be indexed for inflation. Creditors would be required to pay an indexation surcharge equal to $1.67 \%$ of the indexable basis of all pre-existing fixed-rate debt but they would be permitted to deduct an additional $1.67 \%$ of indexable basis from nominal income in computing taxable interest income. Similarly, debtors would receive a tax credit equal to $1.67 \%$ of the indexable basis of all pre-existing fixed-rate debt but they also would be required to reduce their interest deduction by this amount. This scheme should be reasonably effective in adjusting the effective pre-tax interest rate faced by parties with pre-existing debt to that which would have been agreed upon had the parties known debt indexation would be applied to their debt.

\section{TREatment of SPEcific Classes of DebT UNDER INDEXation}

Debt indexation proposals have frequently been criticized on the grounds of administrative complexity. ${ }^{168}$ This part attempts to counter this criticism by suggesting administrable methods for indexing various classes of debt. For simplicity of exposition, this part will not attempt to integrate transition rules with the methods

$1660.0167=0.05 \times 0.25 /(1-0.25)$. See supra note 159 and accompanying text.

167 Some such delay in effective date would be necessary on administrative rather than transitional grounds.

${ }^{168}$ See supra note 2 and accompanying text. 
suggested. The major administrative difficulty in implementing debt indexation is the determination of the taxpayer's indexable basis in his debt. ${ }^{169}$ Because this is also the major administrative problem in implementing transition rules for indexation, the following discussion should be readily extensible to the transition area.

This part assumes that a single inflation indexation rate will be applied to debt held for any portion of a taxpayer's taxable year and that this rate will be calculated and published by the Internal Revenue Service. Use of quarterly or monthly indexation rates clearly would be more precise and hence less subject to abuse. However, the additional administrative burden entailed by the use of multiple rates within a taxable year is probably not warranted. Given this assumption, where the principal amount of a debt varies over the course of a taxable year, indexation can be based on the average balance of the debt during that year. Similarly, where debt is held for only a fraction of a taxable year, the annual indexation adjustment can simply be prorated over the holding period. ${ }^{170}$ For simplicity, the following discussion assumes that debt is always held for a full taxable year.

\section{A. Qualified Residence Indebtedness}

Homeowners have traditionally been accorded a number of tax preferences. ${ }^{171}$ Requiring homeowners to index qualified resi-

169 Once the taxpayer's indexable basis is determined, calculation of the inflation adjustment itself is quite simple. The taxpayer's indexable basis is multiplied by the inflation rate to produce the inflation adjustment. See, e.g., supra note 26 and accompanying text.

${ }^{170}$ Cf. I.R.C. $\$ 1271(\mathrm{a})(3)-(\mathrm{a})(4)$ (1988) (ratable characterization of gain from sale of short-term government obligations acquired at a discount and of gain from sale of short-term nongovernment original issue discount obligations as ordinary income); id. $\$ 1272$ (a) (ratable imputation within each accrual period of original issue discount on long-term debt instruments); id. $\$ 1276$ (ratable accrual of market discount); id. $\$ \S 1281,1283$ (ratable inclusion in income of acquisition discount and interest on certain short-term obligations).

${ }^{171}$ Like all owners of capital assets, homeowners benefit from the tax deferral created by the realization requirement, see id. $\S 1001$, and from the step-up in basis at death. See id. $\$ 1014$. The value of these benefits is magnified by the liberal rollover provisions applicable to the sale of a principal residence. See $i d$. $\$ 1034$. Also, homeowners who are age 55 or older are permitted a one-time exclusion of up to $\$ 125,000$ of gain from the sale of a principal residence. See id. $\$ 121$. Finally, although the deductibility of consumer interest was generally eliminated by the 1986 Tax Reform Act, Congress created an exception for "qualified residence interest" that retains the deductibility of most home mortgage interest. See id. $\S 163(h)(2)(D)$. 
dence indebtedness would significantly reduce the tax benefit of home ownership. ${ }^{172}$ Congress might, therefore, choose to exempt qualified residence indebtedness from indexation by the borrower. ${ }^{173}$ Presumably, home mortgage lenders would still be permitted to index. ${ }^{174}$ Although this would produce a revenue loss, ${ }^{175}$ it would be a loss that reflected the cost of subsidizing home ownership, a policy clearly espoused by Congress.

One problem with such an exemption is that it would provide an incentive to homeowners to acquire and maintain the maximum amount of unindexed home mortgage debt and to invest any proceeds in excess of those needed to finance the home in indexed assets. ${ }^{176}$ Even if Congress decided to subsidize home ownership by exempting home mortgage borrowers from indexation, it probably would not want to subsidize those homeowners who do not need to borrow to finance the purchase of their homes. This arbitrage opportunity could be eliminated by limiting any incomereducing indexation adjustment to the amount that exceeds the foregone home mortgage indexation adjustment. ${ }^{177}$

Assuming that Congress decides not to exempt qualified residence indebtedness from indexation by the borrower, the administrative problems involved with indexing home mortgage debt would be minimal. To calculate his indexation adjustment, a

172 Interest rates would fall somewhat as a result of debt indexation, benefiting homeowners. But it is unlikely that rates would fall enough to offset fully the tax burden of indexing home mortgage debt because mortgage-holding homeowners are generally relatively high bracket taxpayers and their lost interest deductions are, therefore, relatively valuable.

173 The Treasury I debt indexation proposal, for example, would have excluded "mortgage ... indebtedness secured by or allocable to [a] principal residence." TREASURY I, supra note 59, at 194-95.

174 Eliminating indexation for home mortgage lenders would cause lenders to demand higher interest rates on home mortgage debt than on indexed debt. Assuming that home mortgage borrowers were exempted from indexation because Congress desired to confer a tax benefit upon them, exempting home mortgage lenders would undermine this benefit by imposing higher interest rates on them. It would also result in tax-exempt lenders becoming the major providers of home mortgage credit, so there would ultimately be little revenue pickup from eliminating indexation for these lenders.

175 See supra notes 80-83 and accompanying text.

176 See TREASURY I, supra note 59, at 198; Halperin \& Steuerle, supra note 1, at 359. Even under a scheme that only indexed debt, homeowners could invest unneeded mortgage proceeds in interest-bearing assets to achieve additional tax deductions. Of course, a similar potential exists under present law via investments in tax-deferred capital assets, so it is unclear how seriously this new arbitrage opportunity should be taken.

${ }^{177}$ See Halperin \& Steuerle, supra note 1 , at $359-60$. 
homeowner would need to know his average mortgage principal balance. This amount would then be multiplied by the inflation indexation rate published by the Internal Revenue Service to produce the indexation adjustment. Homeowners already need to know the amount of qualified home mortgage interest paid if they wish to deduct it. ${ }^{178}$ Many homeowners obtain this figure from the mortgagee, who is generally required to report to the homeowner the amount of mortgage interest he has received. ${ }^{179}$ Some mortgagees also report the average mortgage principal balance, and the marginal cost of requiring all mortgagees to do so would be very small. Most homeowners could thus obtain their average mortgage principal balance directly from these reports without any need for complicated calculations. For those homeowners who would need to compute their own average balance, use of approximate methods could be authorized by Regulation to simplify this process. Average principal balance is already needed by some taxpayers to determine the amount of interest eligible for the qualified residence interest deduction, and the Treasury has already promulgated regulations authorizing the use of approximate methods for the computation of average principal balance in this context. ${ }^{180}$ These same methods could be used to calculate the average principal balance for indexation.

\section{B. Consumer Debt and Commercial Credit}

Most interest on consumer debt is classified as nondeductible personal interest. ${ }^{181}$ Where interest is nondeductible, no indexation adjustment by the borrower is necessary. Otherwise, interest is generally deductible as a trade or business, investment, or passive activity expense, subject to certain limitations. ${ }^{182}$ Computation

${ }^{178}$ If a homeowner chooses not to deduct qualified home mortgage interest, it is unnecessary to index his home mortgage debt.

${ }^{179}$ Section $6050 \mathrm{H}$ of the Code, see I.R.C. $\$ 6050 \mathrm{H}(1988)$, imposes a return requirement on any person who, in the course of his trade or business, receives $\$ 600$ or more of mortgage interest from any individual during a calendar year. These mortgagees are also required to report to the mortgagor on a Form 1098, or a comparable information return, the amount of mortgage interest received. See Treas. Reg. § 1.6050H-2(b) (1988).

${ }_{180}$ These methods include computation of the average principal balance by dividing interest paid by the annual interest rate, computation by averaging beginning and ending principal balances, and use of the highest annual principal balance as an approximation for average principal balance. See Treas. Reg. $\$ 1.163-10 T(h)(1988)$.

${ }^{181}$ See I.R.C. $\$ 163(\mathrm{~h})(2)(1988)$.

182 See id. § 163 . 
of the indexation adjustment for such debt could be facilitated by requiring institutional lenders to report average principal balances. Because interest on revolving credit is usually calculated on the basis of average balance, the incremental burden of requiring lenders to report this information should be minimal. Furthermore, indexation will require lenders to calculate their overall average outstanding balance in order to compute their own indexation adjustment. This calculation will presumably involve tracking the average balances of outstanding debt, so even lenders who do not calculate interest on the basis of average principal balances should have this information available. ${ }^{183}$ Taxpayers with deductible interest expenses could calculate their inflation adjustments by multiplying the reported average balance by the applicable indexation rate for their taxable year. To further facilitate indexation for calendar year taxpayers, lenders might also be required to perform this calculation and to report interest expense net of the inflation adjustment.

\section{Bank and Money Market Deposits}

Financial institutions are presently required to furnish taxpayers with an annual statement of aggregate interest payments. ${ }^{184}$ Computation of the indexation adjustment for depositors could be facilitated by modifying these reporting requirements to include the reporting of average balances, or even of interest income net of the inflation adjustment. Interest on deposits is also generally calculated on the basis of average balances, so this new requirement should impose relatively little additional burden on the reporting institutions.

183 Financial lenders might instead be permitted to calculate their indexation adjustment directly from their net equity. In this case, tracking and reporting individual average balances would be a more significant burden but certainly not an unbearable one.

184 With some limited exceptions, see I.R.C. $\$ 6049(b)(2)(1988), \S 6049$ of the Code, see I.R.C. $\S 6049$ (1988), imposes a return requirement on any person making aggregate interest payments of $\$ 10$ or more to another person during a calendar year. These borrowers are also required to report to the payee on a Form 1099, or a comparable information notice, the amount of interest paid. See Treas. Reg. $\S 1.6049-6$ (1983). 


\section{Government and Corporate Bonds}

Theoretically, a bond should be indexed based upon the bondholder's basis in the bond, not the actual market value of the bond. ${ }^{185}$ The amount of the indexation adjustment should be the taxpayer's basis in the bond multiplied by the percentage increase in the inflation index. Because the Code does not generally impose mark-to-market taxation on bonds, ${ }^{186}$ there would be no administrative advantage to indexing based on actual market value rather than basis.

Indexing debt will not be necessary for most issuers of government bonds because such issuers are typically tax exempt. ${ }^{187}$ For issuers of corporate bonds, indexation will present only an incremental burden. The indexation adjustment will simply be the corporation's total basis in its outstanding bonds multiplied by the annual percentage increase in the inflation index. This calculation will generally be very simple. ${ }^{188}$ There should be no additional recordkeeping burden because corporations already track their basis in outstanding bonds for both tax and accounting purposes.

The potential complexity of indexation for holders of government and corporate bonds is far greater than for issuers. In addition to purchase price and original issue discount, a bondholder's basis can also be affected by acquisition premium, market discount, and amortizable bond premium, all of which complicate

185 The bondholder's basis represents the capital cost of producing interest income. Because the basis is denominated in historical, uninflated dollars, while interest income is measured in current, inflated dollars, it is the bondholder's basis that must be adjusted to current dollars to neutralize the effect of inflation on the measurement of net income. Cf. supra note 65 (noting that a failure to adjust for inflation in computing net income greatly overstates real capital income).

${ }^{186}$ Dealers in securities may, however, value their inventory of securities either at market value or at the lower of cost or market. See Treas. Reg. $\$ 1.471-5$ (as amended in 1987). The President's 1993 budget proposal would require securities dealers to value securities held as inventory at market value. See STAFF OF JOINT COMM. ON TAX'N, 102 CONG., 2D Sess., Summary of Revenue Proposals in the President's FISCAL YEAR 1993 BUDGET 30-31 (Comm. Print 1992).

${ }^{187}$ See I.R.C. \$ 501(c)(1) (1988); see also ROSE \& CHOMMIE, supra note 78, at $\$ 11.03$. To the extent that issuers of government debt may not be tax-exempt in some instances, indexation by such issuers would be similar to indexation by corporate issuers.

${ }^{188}$ To the extent that some corporate bonds are original issue discount instruments, basis must be adjusted annually to accrue original issue discount. This adjustment is already made under present law as the original issue discount is deducted under $\$ 163(e)$ of the Code, see I.R.C. $\$ 163(e)(1988)$, so indexation would pose no additional burden in this respect. 
the computation of the indexation adjustment. This additional complexity is exacerbated by the fact that many bondholders are individual taxpayers. An administrable indexation scheme for these bondholders must, therefore, rely on a combination of increased reporting requirements and the assumed sophistication of certain classes of bondholders.

In general, a bondholder's indexation adjustment will be his average basis in the bond for the taxable year multiplied by the annual indexation rate. Consider the original purchaser of a government or corporate bond issued at par. The bondholder's basis in this instance is the par value of the bond, and this basis is fixed for as long as the original purchaser holds the bond. These bondholders could be required to attain their basis annually from their own financial records. A better solution, however, would be to require issuers to include this figure on the annual interest statement that they are already required to send to bondholders. ${ }^{189}$ This new reporting requirement would impose only a slight incremental burden on bond issuers and the bondholder could simply use the reported figure as his basis for indexation.

This reporting requirement could also facilitate indexation for original purchasers of original issue discount bonds ("OID bonds"). Instead of reporting par value, the issuer of an OID bond could be required to report the bond's adjusted issue price. ${ }^{190}$ The issuer already needs to maintain this figure in order to calculate the amount of original issue discount he may take as an interest deduction, ${ }^{191}$ so the additional reporting burden would be minimal. Holders of OID bonds could easily approximate their average basis by adding half of their current original issue discount to the adjusted issue price because these would both be reported on the annual Form 1099-OID sent to the bondholder. Alternatively, issuers could be required to make this calculation and report the approximate indexable basis figure. An exact method based on average accrued daily portions of original issue discount could be prescribed for large bondholders to avoid abuse. This reporting requirement would simplify indexation for most original holders of OID bonds because they would not need to compute their indexable basis.

${ }^{189}$ See id. § 6049; Treas. Reg. § 1.6049-6 (1983).

${ }^{190}$ See I.R.C. \$ 1272(a)(3)-(4) (1988).

${ }^{191}$ See id. $\S 163(\mathrm{e})$. 
When a bond is purchased after its original issue, the secondary bondholder's initial basis is his cost, a figure not generally known to the bond's original issuer. When such a bond is purchased for less than its stated redemption price or, in the case of a bond with original issue discount, for less than its issue price plus accrued original issue discount, this deficit is called market discount. ${ }^{192}$ Market discount need not be recognized periodically like original issue discount-instead it may be accrued and recognized upon disposition of the bond. ${ }^{193}$ The bondholder's basis will therefore be less than the anticipated value of the market discount bond. This will produce an anticipated tax deferral for the holder of the market discount bond. ${ }^{194}$ This tax deferral problem is independent from the problems addressed by debt indexation ${ }^{195}$ and is one our tax system has generally been willing to tolerate. ${ }^{196}$ It is proper, therefore, to index such bonds by the bondholder's basis, rather than attempting to recapture any of the benefit of this tax deferral through a reduced indexation adjustment. Because market discount is not recaptured over the term of the bond, the bondholder's basis will always be the same as the basis would have been for the original purchaser of the bond minus the amount of market discount at purchase. The average basis for holders of market discount bonds will be easily calculated by subtracting the known amount of market discount from the indexable basis figure reported by the issuer on the annual interest statement.

When a bond is purchased at a price exceeding it original issue price plus any accrued original issue discount, this excess, called acquisition premium, is used to reduce the amount of original issue discount subsequently recognized by the secondary bondholder. ${ }^{197}$ Because proper treatment of acquisition premium already demands sophisticated computations and extensive record keeping, it is reasonable to require taxpayers holding such instruments to

192 See id. \$1278(a)(2); see also RoSE \& CHOMMIE, supra note 78, at \$7.12.

${ }^{199}$ See I.R.C. \$ 1276 (1988). Bondholders may elect to recognize market discount as it accrues. See id. $\$ 1278(\mathrm{~b})$.

194 The Code attempts to limit the advantage of this deferral by requiring the deferral of interest deductions on debt incurred or continued to purchase or carry market discount bonds. See id. \$ 1277.

195 They are related only in that inflation increases the value of tax deferral, magnifying the problem.

196 But see I.R.C. $\$ 453 \mathrm{~A}$ (1988) (imposing a surtax to recapture benefit of deferred tax liability in certain installment sales); $i d$. $\$ 1291$ (imposing a surtax to recapture benefit of deferral on income from passive foreign investment companies).

${ }^{197}$ See id. \$1272(a)(7), (b)(4). 
perform their own average basis calculations for purposes of computing their indexation adjustment. Finally, when a bond is purchased for a price exceeding its stated redemption price, this excess may, at the taxpayer's election, be treated as amortizable bond premium and used to offset interest income received on the bond. ${ }^{198}$ Again, because such treatment already requires sophisticated calculations, including annual adjustments to basis, and because amortization is elective, taxpayers making such an election should be capable of calculating their average basis.

\section{E. Indexed Debt}

It is possible for taxpayers to construct variable rate debt instruments that are automatically indexed for inflation. These instruments typically bear a fixed real interest rate and provide for periodic adjustments in the outstanding debt principal or supplemental interest payments at a variable rate based on some inflation index. The taxation of such instruments under current law is complex. The Treasury has issued temporary regulations prescribing the tax treatment of price level adjusted mortgages, one form of indexed debt. ${ }^{199}$ Under these regulations, a certain portion of the variable interest on a price level adjusted mortgage is treated as original issue discount. ${ }^{200}$ Treatment of other indexed debt instruments is less certain, but would likely invoke the original issue discount rules for variable rate debt. ${ }^{201}$

Under a system of debt indexation, the treatment of indexed debt would be much simpler. Assuming that the inflation index used by debt instruments was the same as the index used by the Code, ${ }^{202}$ taxable interest would equal the real, fixed-rate interest on the indexed debt. All the variable rate interest, whether paid as supplemental interest or added to debt principal, could simply be excluded from taxable income. There would be no need to subject the debt to the original issue discount rules.

${ }^{198}$ See id. $\$ 171$.

${ }^{199}$ See Treas. Reg. \$ 1.1275-6T (1990).

200 See id. \$ 1.1275-6T(d).

201 See Prop. Treas. Reg. $\S 1.1275-5,51$ Fed. Reg. 12094 (1986). In effect, any portion of the indexation adjustment that is added to the principal balance rather than being paid currently as interest must be recognized as current interest through the original issue discount rules.

202 It is unlikely that issuers of indexed debt would choose a different index at the expense of greater complexity. The debt indexation rules might also choose to respect the use of other inflation indices provided they meet certain general criteria. 


\section{F. De Minimis Rules for Individuals}

Along with new reporting requirements, the use of de minimis rules could substantially reduce the administrative burden of debt indexation for individual taxpayers. The Treasury I debt indexation proposal, for example, would have excluded the first $\$ 5,000$ of an individual's interest expense from indexation. ${ }^{203}$ Given the present nondeductibility of personal interest and the imposition of new reporting requirements, such a generous exclusion is unnecessary. ${ }^{204} \mathrm{~A}$ more reasonable de minimis rule might exempt individuals with net debt not exceeding $\$ 10,000$ from debt indexation. ${ }^{205}$ An alternative approach would be to exempt only specific types of loans not exceeding some threshold amount. ${ }^{206}$

\section{CONCLUSION}

The magnitude of the tax base distortions created by the failure to index debt has declined substantially since the early 1980s due to both lower rates of inflation and lower tax rates. Furthermore, the introduction of interest tracing rules has reduced the availability of tax arbitrage based on the taxation of nominal interest. Nonetheless, even at present rates of inflation and taxation, our current system of taxing debt continues to produce inequities and economic distortions that could be eliminated by debt indexation. The

203 See TREASURY I, supra note 59, at 195. The Treasury I proposal based its indexation adjustment on aggregate interest rather than principal balances. See supra note 92.

204 With annual inflation of $6 \%$, Treasury I would have imposed a fractional exclusion rate of 50\%. See TREasurY I, supra note 59, at 196 . Thus the $\$ 5,000$ de minimis exclusion would have permitted some taxpayers an additional $\$ 2,500$ deduction. Assuming a maximum tax rate of $33 \%$, this exclusion could have been worth up to $\$ 825$. This $\$ 5,000$ de minimis exclusion was also partially justified as a transition rule, although Treasury I never stated when this exclusion would be reduced or eliminated. See id. at 198. As a transition rule, this exclusion, which is similar to a phased-in effective date rule, is quite unsatisfactory. See supra notes 15556 and accompanying text.

${ }^{205}$ Again assuming annual inflation of $6 \%$ and a maximum tax rate of $33 \%$, the maximum tax cost of this de minimis exemption would be less than $\$ 200$. De minimis rules of similar generosity exist elsewhere in the Code. See, e.g., I.R.C. $\$ 7872(c)(2)$ (1988) (providing de minimis exception from the below-market interest rules for gift loans between individuals not exceeding $\$ 10,000$ ).

${ }^{206}$ Cf. id. $\$ 7872$ (c)(2)-(3) (1988) (providing $\$ 10,000$ de minimis exception from below-market interest rules for gift loans between individuals, compensation-related loans, and corporate-shareholder loans). Adopting an identical exception for debt indexation would simplify the integration of indexation with the existing interest provisions. 
present climate of lower inflation and lower tax rates presents an ideal opportunity for a transition to debt indexation because it reduces the magnitude of the windfalls that such a transition would necessarily create. The administrative burden of debt indexation for individual taxpayers could be minimized through new reporting requirements and de minimis rules. Only sophisticated taxpayers would be likely to experience a significant additional burden as a result of indexation. Congress has already demonstrated its willingness to impose similarly complex rules in taxing debt. Debt indexation should not be dismissed as administratively infeasible and even under the present economic climate, it remains a reform worthy of serious consideration. 


$$
\text { . }
$$

